\title{
Comparison of MODIS-derived land surface temperatures with ground surface and air temperature measurements in continuous permafrost terrain
}

\author{
S. Hachem ${ }^{1}$, C. R. Duguay ${ }^{1}$, and M. Allard ${ }^{2}$ \\ ${ }^{1}$ Interdisciplinary Centre on Climate Change and Department of Geography and Environmental Management, \\ University of Waterloo, Waterloo, Ontario N2L 3G1, Canada \\ ${ }^{2}$ Centre d'études nordiques and Département de Géographie, Université Laval, Québec, Québec G1K 7P4, Canada \\ Correspondence to: S. Hachem (hachem_sonia@yahoo.fr)
}

Received: 29 April 2011 - Published in The Cryosphere Discuss.: 27 May 2011

Revised: 31 December 2011 - Accepted: 3 January 2012 - Published: 13 January 2012

\begin{abstract}
Obtaining high resolution records of surface temperature from satellite sensors is important in the Arctic because meteorological stations are scarce and widely scattered in those vast and remote regions. Surface temperature is the primary climatic factor that governs the existence, spatial distribution and thermal regime of permafrost which is a major component of the terrestrial cryosphere. Land Surface (skin) Temperatures (LST) derived from the Moderate Resolution Imaging Spectroradiometer (MODIS) sensor aboard the Terra and Aqua satellite platforms provide spatial estimates of near-surface temperature values. In this study, LST values from MODIS are compared to ground-based nearsurface air $\left(T_{\text {air }}\right)$ and ground surface temperature (GST) measurements obtained from 2000 to 2008 at herbaceous and shrub tundra sites located in the continuous permafrost zone of Northern Québec, Nunavik, Canada, and of the North Slope of Alaska, USA. LSTs (temperatures at the surface materials-atmosphere interface) are found to be better correlated with $T_{\text {air }}$ (1-3 $\mathrm{m}$ above the ground) than with available GST ( $3-5 \mathrm{~cm}$ below the ground surface). As $T_{\text {air }}$ is most often used by the permafrost community, this study focused on this parameter. LSTs are in stronger agreement with $T_{\text {air }}$ during the snow cover season than in the snow free season. Combining Aqua and Terra LST-Day and LST-Nigh acquisitions into a mean daily value provides a large number of LST observations and a better overall agreement with $T_{\text {air }}$. Comparison between mean daily LSTs and mean daily $T_{\text {air }}$, for all sites and all seasons pooled together yields a very high cor-
\end{abstract}

relation $\left(R=0.97\right.$; mean difference $(\mathrm{MD})=1.8^{\circ} \mathrm{C}$; and standard deviation of $\left.\mathrm{MD}(\mathrm{SD})=4 \cdot 0^{\circ} \mathrm{C}\right)$. The large $\mathrm{SD}$ can be explained by the influence of surface heterogeneity within the MODIS $1 \mathrm{~km}^{2}$ grid cells, the presence of undetected clouds and the inherent difference between LST and $T_{\text {air }}$. Retrieved over several years, MODIS LSTs offer a great potential for monitoring surface temperature changes in high-latitude tundra regions and are a promising source of input data for integration into spatially-distributed permafrost models.

\section{Introduction}

The 2007 Intergovernmental Panel on Climate Change (IPCC) reports a global temperature increase of $0.74{ }^{\circ} \mathrm{C}$ over the last $100 \mathrm{yr}$. Observational records show that average temperature in the Arctic has risen at almost twice the rate as the rest of the world in the past few decades (Zhou et al., 2001; Hinzman et al., 2005; IPCC, 2007). Near-surface air temperature trends in the Arctic have been shown to be greater for inland regions than coastal/ocean regions (Comiso, 2003). There are clear signs that change is ongoing in many environmental variables (Kane, 2005), including permafrost whose temperature increase results in a deepening of the active layer and thermokarst (Romanovsky et al., 2002). In the context of greenhouse gas emissions, permafrost thawing could contribute to the release of a significant amount of $\mathrm{CH}_{4}$ and $\mathrm{CO}_{2}$ stored in organic frozen soils (Christensen et al., 2004; 
Serreze et al., 2000). It is therefore important to be able to monitor the evolution of the surface thermal regime of permafrost at regional and global scales. However, climate stations that provide near-surface air and ground surface temperatures are scarce and widely scattered in the vast Arctic regions. Spatial interpolation may be inaccurate when few point measurements are available. As a result, a strong interest is being expressed by the permafrost science community to use satellite-derived land surface temperature (LST) either as a replacement or in conjunction with more spatially limited ground surface temperature (GST) or near-surface air temperature $\left(T_{\text {air }}\right)$ from meteorological stations in permafrost models (Marchenko et al., 2009; Heim et al., 2011). Here we focused on the comparison of these three parameters to evaluate the applicability of LSTs for permafrost mapping.

There has been interest for some time already in using spaceborne LST measurements for understanding biological, hydrological and climatological systems which reflect the results of surface-atmosphere interactions and energy exchanges between the atmosphere and the ground, and for climate monitoring at high latitudes. A few studies have utilized LST obtained from satellite sensors (NOAA AVHRR, GOES, and SSM/I) to observe temperature variability and trends in Boreal and Arctic regions (Comiso, 2003; Goïta et al., 1997; Han et al., 2004; Mialon et al., 2007; Traoré et al., 1997). LST products derived from the Moderate Resolution Imaging Spectroradiometer (MODIS) are increasingly being used to study various land components and processes at northern latitudes. Recent applications include vegetated areas (Coops et al., 2009), $\mathrm{CO}_{2}$ exchange (Schubert et al., 2010), and permafrost at regional (Hachem et al., 2009) and local scales (Langer et al., 2010; Westermann et al., 2011). MODIS $1 \mathrm{~km}$ LST products have been cross-compared or validated against ground-based temperature measurements over homogeneous surfaces such as lakes (Wan et al., 2002a, b, 2004; Hook et al., 2007; Wan, 2008; Crosman and Horel, 2009), rice crops (Coll et al., 2005, 2009; Wan et al., 2004; Galve et al., 2007), silt-playas (Snyder et al., 1997), and densely vegetated areas (Wan, 2008). The $1 \mathrm{~km}$ products have also been validated with the alternative radiance-based ( $R$-based) method over a lake, rice crops (Wan and Li., 2008; Coll et al., 2009) and dense forest (Coll et al., 2009). In addition, comparisons have been conducted between $T_{\text {air }}$ at meteorological stations and MODIS $5 \mathrm{~km}$ LST products and upscaled to $25 \mathrm{~km}$ around the globe (Bosilovitch, 2006). Most validations/comparisons have been made at mid- and lowlatitude sites. Recently, Langer et al. (2010) and Westermann et al. (2011) compared summertime MODIS LST data with those obtained with a thermal imaging system installed on a mast $10 \mathrm{~m}$ above the ground at two permafrost sites. They report differences of less than $2 \mathrm{~K}$ between the two sets of measurements under clear-sky conditions, with occasionally larger differences when clouds are not properly detected in the MODIS LST product. Validations with thermal infrared radiometers made on several homogeneous sites within a $1 \mathrm{~km}$ pixel area, revealed that the differences found between the LST and the field-based radiometer measurements come from essentially two sources: undetected clouds (Westermann et al., 2011) and surface heterogeneity within the pixel (Klene et al., 2001).

In regions underlain by permafrost, GST is the principal variable that drives the thermal regime of the ground; it is estimated in spatially distributed models simulating the thermal regime of permafrost. To date, however, temperature fields used as input in those models have largely been derived through spatial interpolation of $T_{\text {air }}$ measurements from a limited number of geographically scattered meteorological stations (e.g. Hinzman et al., 1998; Shiklomanov and Nelson, 2002; Sazonova and Romanovsky, 2003) or, more recently, have been provided by coarse resolution (e.g. $2.5^{\circ}$ latitude $\times 2.5^{\circ}$ longitude) atmospheric reanalysis data such as NCEP/NCAR (Shiklomanov et al., 2007). $T_{\text {air }}$ is still widely used for permafrost mapping because of the scarcity of sites where GST is measured; most often, corrections such as nfactors are applied to account for surface factors, particularly snow cover. But even $T_{\text {air }}$ data from meteorological stations are either not spatially representative (field) or too coarse (reanalysis) for regional permafrost studies. MODIS LST products are of particular interest since they offer the potential to retrieve LST on a daily basis, over large areas, and at a spatial resolution of $\sim 1 \mathrm{~km}$.

The primary objective of this research was to compare the $1 \mathrm{~km}$ LST product (i.e. the clear-sky "skin" temperatures) retrieved from the MODIS sensor aboard the Terra and Aqua satellite platforms to GST and $T_{\text {air }}$ measured day and night, year-round, at meteorological stations to establish how close the LSTs are to these ground-based measurements. Both GST and $T_{\text {air }}$ are compared herein with MODIS LSTs because GSTs drive in fact the thermal regime of permafrost; however $T_{\text {air }}$ is most often available from meteorological stations and is therefore also used by permafrost specialists and modelers. The lack of GST measurements is a problem in the Arctic and, similar to ice surfaces, $T_{\text {air }}$ had to be used for verification of LSTs (Hall et al., 2004). One purpose of this study is to verify the correspondence between meteorological station data and MODIS data (as in Bosilovich, 2006, for $5 \mathrm{~km}^{2}$ LSTs) in order to establish a more general relation than through validation using thermal radiometers or imaging systems which, unlike $T_{\text {air }}$, are limited temporally (summer only) and spatially (2-3 test sites) (e.g. Langer et al., 2010; Westermann et al., 2011). The sites we use for comparisons are located in high latitude regions characterized by heterogeneous tundra surface types in the continuous permafrost zone of Northern Québec, Canada, and the North Slope of Alaska, USA.

$T_{\text {air }}$ is measured in ventilated shelters located $1-2 \mathrm{~m}$ above the ground at meteorological stations. GST is defined as the temperature at the surface of the ground. In most cases, that surface is covered by different types of materials which are the organic layer, vegetation and snow in winter, often 
altogether referred to as the buffer layer. LSTs are measured from satellites that can only observe the surface of the Earth, which corresponds, in fact, to the various above mentioned materials. LSTs are different from both $T_{\text {air }}$ and GSTs and, as a result, the comparisons made here attempt to evaluate the degree of correspondence between these three parameters. We conclude this paper with a summary of the key findings of this research and implications for permafrost studies.

\section{Data and methods}

\subsection{Rationale for the selection of MODIS on the terra and aqua platforms}

\subsubsection{Land surface temperature retrieval}

The LSTs from the MODIS sensor are available from NASA's Warehouse Inventory Search Tool website ${ }^{1}$. The V5 level 3 MODIS LST (MOD11A1 and MYD11A1) products were used in this study. LST is retrieved from MODIS sensors based on the use of the day-night split-window algorithm (Wan and Dozier, 1996) where two unknowns need to be determined: the emissivity of the surfaces under consideration in the two adjacent spectral windows (channels around 11 and $12 \mu \mathrm{m})$ and the atmospheric transmission. As MODIS acquires several data simultaneously in multiple channels, the atmospheric transmission is derived directly from the atmospheric concentrations contained in the MOD07_L2 atmospheric product (Wan, 2007). The emissivity of land surfaces cannot be directly retrieved by the sensor, but other available MODIS-derived products are used to estimate/calculate emissivities as a function of time: land cover (MOD12Q1) and daily snow cover (MOD10_L2) products (Wan, 2007). Then MODIS LST products are generated from measurements in the thermal infrared of channel $31(10.78-11.28 \mu \mathrm{m})$ and channel 32 (11.77-12.27 $\mu \mathrm{m})$ (Wan and Dozier, 1996; Wan et al., 2002; Wan, 2008). With the MODIS sensors aboard NASA's Aqua and Terra satellites, maximum surface temperature errors have been reported to range between 2 and $3 \mathrm{~K}$, with a standard deviation of 0.009 due to emissivity errors (Wan and Li, 1997).

\subsubsection{High temporal and spectral resolution, and moderate spatial resolution}

The level 3 MODIS LST products provide only two values for each satellite (Terra and Aqua) and MODIS sensors have a $1 \mathrm{~km}$ spatial resolution in the thermal infrared. The twicedaily temporal resolution is of particular interest as it allows

\footnotetext{
${ }^{1}$ https://wist.echo.nasa.gov/api/; names of products used: MODIS/TERRA LAND SURFACE TEMPERATURE/EMISSIVITY DAILY L3 GLOBAL $1 \mathrm{KM}$ SIN GRID V005 and MODIS/AQUA LAND SURFACE TEMPERATURE/EMISSIVITY DAILY L3 GLOBAL 1KM SIN GRID V005
}

one to monitor the evolution of surface temperatures throughout the year. At the pixel scale (within a $1 \mathrm{~km}^{2}$ grid-cell), however, variations in topography, surface materials, vegetation and snow cover can influence the temperatures measured from spaceborne thermal sensors. As the Level 3 MODIS LST product is distributed with two sets of data named LSTDay and LST-Night, the frequency of acquisition can be as much as 4 times per day if Terra and Aqua data are combined. Thus, the more frequent coverage can improve the calculation of a mean daily LST, which is of particular interest to permafrost mapping and modeling efforts. It is important to note that, at high latitudes with large seasonal variations in daylight duration, the LST-Day and LST-Night MODIS name convention is not related to daylight but rather with ascending (LST-Day) and descending acquisition modes (LSTNight).

Although, the first NOAA satellites were launched in 1979, providing a long time series for studying Arctic climate change over a period of more than $25 \mathrm{yr}$ (Comiso, 2003), a temporal drift is known to occur during the lifetime of NOAA satellites which can result in a local overpass time variation of up to $4 \mathrm{~h}$, especially in the afternoon (Traoré et al., 1997) leading to a significant cooling of the LST measurements (Gleason et al., 2002, Jin and Treadon, 2003). However, Terra and Aqua satellites, which have been active since 2000 and 2002, respectively, do not suffer from such drift. This choice thus directs the research towards the evaluation of MODIS LST for surface temperature mapping in the Arctic rather than for making a time series analysis of trends and variability in surface temperatures. In the following sections LST refers to LST MODIS products.

\subsection{Location of study sites and data description}

The ground-based meteorological stations for this study were located in tundra areas underlain by continuous permafrost, north of treeline, in Northern Québec (Canada) and Northern Alaska (USA). The characteristics of each site for which GST and $T_{\text {air }}$ were compared to LSTs are given in Table 1. At some stations GST and $T_{\text {air }}$ from meteorological stations were only available until the end of 2003 , for other stations until 2007 or 2008.

\subsubsection{Northern Québec (Nunavik) stations, Canada}

Five meteorological stations within three Inuit villages recorded hourly GST (3-5 $\mathrm{cm}$ below ground) and $T_{\text {air }}(1-$ $2 \mathrm{~m}$ above ground) corresponding to Terra and Aqua overpass times during the period 2000-2008 (Fig. 1). Three stations are located near the village of Salluit: Sila, Tiki (for Tikiraatsiaq), and the Salluit Airport (SalA in Table 1). The fourth station is situated in Kangiqsualujjuaq on the southeast coast of Ungava Bay and the fifth station, operated by Environment Canada, is located in Kuujjuaq. 
Table 1. Characteristics of the field sites used as reference stations.

\begin{tabular}{|c|c|c|c|c|c|c|c|}
\hline \multirow[t]{2}{*}{ Station Name } & \multicolumn{2}{|c|}{ Station coordinates } & \multirow{2}{*}{$\begin{array}{l}\text { Height Tair }(\mathrm{m}) \\
\text { /frequency of } \\
\text { measure ments } \\
\text { hourly }\end{array}$} & \multirow{2}{*}{$\begin{array}{l}\text { Depth GST }(\mathrm{cm}) \\
\text { /frequency of } \\
\text { measure ments: * }\end{array}$} & \multirow[t]{2}{*}{ Elevation (m) } & \multirow[t]{2}{*}{ Vegetation cover } & \multirow[t]{2}{*}{ Soil Characteristics } \\
\hline & $\begin{array}{l}\text { Latitude } \\
\qquad(\mathrm{N})\end{array}$ & $\begin{array}{l}\text { Longitude } \\
\text { (W) }\end{array}$ & & & & & \\
\hline \multicolumn{8}{|l|}{ Alaska } \\
\hline $\begin{array}{l}\text { West Dock } \\
\text { (WD) }\end{array}$ & $70^{\circ} 22^{\prime} 50^{\prime \prime}$ & $148^{\circ} 33^{\prime} 39^{\prime \prime}$ & 1 & - & $7-6$ & $\begin{array}{l}\text { Marshy drained lake basin } \\
\text { tundra }\end{array}$ & $\begin{array}{l}\text { Organic overlying layers } \\
\text { of fine sans and silts }\end{array}$ \\
\hline $\begin{array}{l}\text { Betty Pingo wetland } \\
\text { (BPW) }\end{array}$ & $70^{\circ} 16^{\prime} 46.3^{\prime \prime}$ & $148^{\circ} 53^{\prime} 44.5^{\prime \prime}$ & 1 & Surface/h & 12 & $\begin{array}{l}\text { Wet sedge tundra and shrub } \\
\text { tundra }\end{array}$ & $\begin{array}{l}\text { Organic overlying layers } \\
\text { of fine sand and silts }\end{array}$ \\
\hline $\begin{array}{l}\text { Betty Pingo upland } \\
\text { (BPU) }\end{array}$ & & & - & Surface/h & & Marshy drier more tundra & \\
\hline $\begin{array}{l}\text { Franklin Bluff } \\
\text { (FB) }\end{array}$ & $69^{\circ} 53^{\prime} 31.8^{\prime \prime}$ & $148^{\circ} 46^{\prime} 4.8^{\prime \prime}$ & 1 & Surface/h & 78 & $\begin{array}{l}\text { Grasses and sedges rooted in } \\
\text { mosses and lichens }\end{array}$ & $\begin{array}{l}\text { Organic materials of variable } \\
\text { thickness overlie silt loam textured } \\
\text { mineral soils poorly drained }\end{array}$ \\
\hline $\begin{array}{l}\text { Sagwon } \\
\text { (SAG) }\end{array}$ & $69^{\circ} 25^{\prime} 27.5^{\prime \prime}$ & $148^{\circ} 41^{\prime} 45.1^{\prime \prime}$ & 1 & Surface/d & 299 & Tussock tundra & $\begin{array}{l}\text { Loamy with peaty surface } \\
\text { layer poorly drained }\end{array}$ \\
\hline $\begin{array}{l}\text { West Kuparuk } \\
\text { (WK) }\end{array}$ & $69^{\circ} 25^{\prime} 34.3^{\prime \prime}$ & $150^{\circ} 20^{\prime} 25.3^{\prime \prime}$ & 1 & $2 / \mathrm{d}$ & 158 & $\begin{array}{l}\text { Moist acidic tundra, } \\
\text { tussock tundra }\end{array}$ & $\begin{array}{l}\text { Loamy with peaty surface } \\
\text { layer poorly drained }\end{array}$ \\
\hline $\begin{array}{l}\text { Upper Kuparuk } \\
\text { (UK) }\end{array}$ & $68^{\circ} 38^{\prime} 24.5^{\prime \prime}$ & $149^{\circ} 24^{\prime} 23.4^{\prime \prime}$ & 1 & $5 / \mathrm{d}$ & 774 & Tussock tundra & - \\
\hline $\begin{array}{l}\text { Imnavait Basin } \\
\text { (IB) }\end{array}$ & $68^{\circ} 36^{\prime} 58.6^{\prime \prime}$ & $149^{\circ} 18^{\prime} 13.0^{\prime \prime}$ & 1 & Surface/d & 937 & $\begin{array}{l}\text { Tussock tundra mosses } \\
\text { lichens shrubs }\end{array}$ & $\begin{array}{l}\text { Soils cold wet poorly drained sil } \\
\text { loams with a high organic content } \\
\text { and include many glacial erratic }\end{array}$ \\
\hline $\begin{array}{l}\text { Imnavait Ridge } \\
\text { (IR) }\end{array}$ & $68^{\circ} 37^{\prime} 27.9^{\prime \prime}$ & $149^{\circ} 19^{\prime} 22.3^{\prime \prime}$ & - & Surface/d & - & - & - \\
\hline $\begin{array}{l}\text { Ivotuk Shrub } \\
\text { (IvShrb) }\end{array}$ & $68^{\circ} 29^{\prime} 12^{\prime \prime}$ & $155^{\circ} 44^{\prime} 34^{\prime \prime}$ & 1 & $2.5 / 3 \mathrm{~h}$ & 570 & Shrub lichen tussock & - \\
\hline Ivotuk Moss (IvMoss) & $68^{\circ} 26^{\prime} 58.6^{\prime \prime}$ & $155^{\circ} 44^{\prime} 71^{\prime \prime}$ & 1 & $1 / 3 \mathrm{~h}$ & & Moss lichen tussock & - \\
\hline \multicolumn{8}{|l|}{ Québec } \\
\hline Sila & $62^{\circ} 11^{\prime} 41.9^{\prime \prime}$ & $75^{\circ} 38^{\prime} 12.8^{\prime \prime}$ & 2 & $3 / \mathrm{h}$ & 45 & Moss lichen tussock & $\begin{array}{l}\text { Organic overlying very shallow } \\
\text { thickness of silt on till }\end{array}$ \\
\hline Tiki & $62^{\circ} 12^{\prime} 14.1^{\prime \prime}$ & $75^{\circ} 41^{\prime} 11.6^{\prime \prime}$ & 2 & $3 / \mathrm{h}$ & 35 & lichen & Bed rock, nor organic matter \\
\hline $\begin{array}{l}\text { Salluit airport } \\
\text { (SalA) }\end{array}$ & $62^{\circ} 11^{\prime} 1.44^{\prime \prime}$ & $75^{\circ} 39^{\prime} 54.9^{\prime \prime}$ & 2 & - & - & - & Rock, asphalt \\
\hline $\begin{array}{l}\text { Kangiqsuallujjuaq } \\
\text { (Kangiq) }\end{array}$ & $58^{\circ} 41^{\prime} 7.83^{\prime \prime}$ & $65^{\circ} 55^{\prime} 6.43^{\prime \prime}$ & 2 & $3 / \mathrm{h}$ & 110 & Lichen and shrub of birch & $\begin{array}{l}\text { Organic overlying shallow } \\
\text { till on bed rock }\end{array}$ \\
\hline $\begin{array}{l}\text { Kuujjuaq } \\
\text { (Env. Can.) }\end{array}$ & $58^{\circ} 06^{\prime} 31.62^{\prime \prime}$ & $68^{\circ} 24^{\prime} 42.44^{\prime \prime}$ & 1.5 & - & 39 & - & - \\
\hline
\end{tabular}

* $\mathrm{h}$ : measured each hour; $\mathrm{d}:$ mean daily temperature; - No Data.

Northern Québec sits on the Canadian Shield. The soils overlying the glacially eroded bedrock are generally thin. Landforms of glacial origin are characterized by till-covered rocky plateaus, coastlines with sands of marine origin, and coastal valley bottoms with glaciomarine clays. At Salluit, vegetation on bedrock and dry soils is composed of mosses and lichens whereas herbaceous plants dominate in the valleys over fine grained soils. Occasional scattered shrubs dot slopes that are sheltered from the wind and covered by snow in the winter. Aerial views show a predominance of mosses and lichens interspersed with islands of bare soil or low shrubs. The meteorological stations at Salluit (Sila, Tiki and SalA) are situated in environments exposed to wind, which reduces the accumulation of winter snow to a thin $(5-10 \mathrm{~cm})$ cover. The Sila stationis located $1.75 \mathrm{~km}$ from the coast at an altitude of $45 \mathrm{~m}$. It is installed on a small till hill surrounded by clay soils. Tiki is located $110 \mathrm{~m}$ from the coast on a rocky promontory advancing into a fjord at an altitude of $35 \mathrm{~m}$. The area surrounding the meteorological station consists primarily of lichen-covered bedrock and thin gravelly soils. The Salluit airport meteorological station (SalA) is located on the top of a plateau surrounding the village at an altitude of $225 \mathrm{~m}$. The area around the tower consists of bedrock covered with patches of till. Kangiqsualujjuaq is a village at the limit between continuous and discontinuous permafrost. Trees with upright growth forms become more prevalent on hill slopes about one kilometer south of the station. Palsas are found at the southern edge of the village. The area immediately surrounding the Kangiqsualujjuaq meteorological station is composed of bedrock and till that support lichens and prostrate scrub, i.e. dwarf birch $20-30 \mathrm{~cm}$ high. (Bouchard, 1990; Gahé, 1987) colonizing a thin till overlying gneissic rock (Table 1). The Kuujjuaq meteorological station is located in an open forest and shrub region at an elevation of $39 \mathrm{~m}$ a.s.l.; the station is on gravelly soils and lichen covered bedrock outcrops occur in the surroundings. 


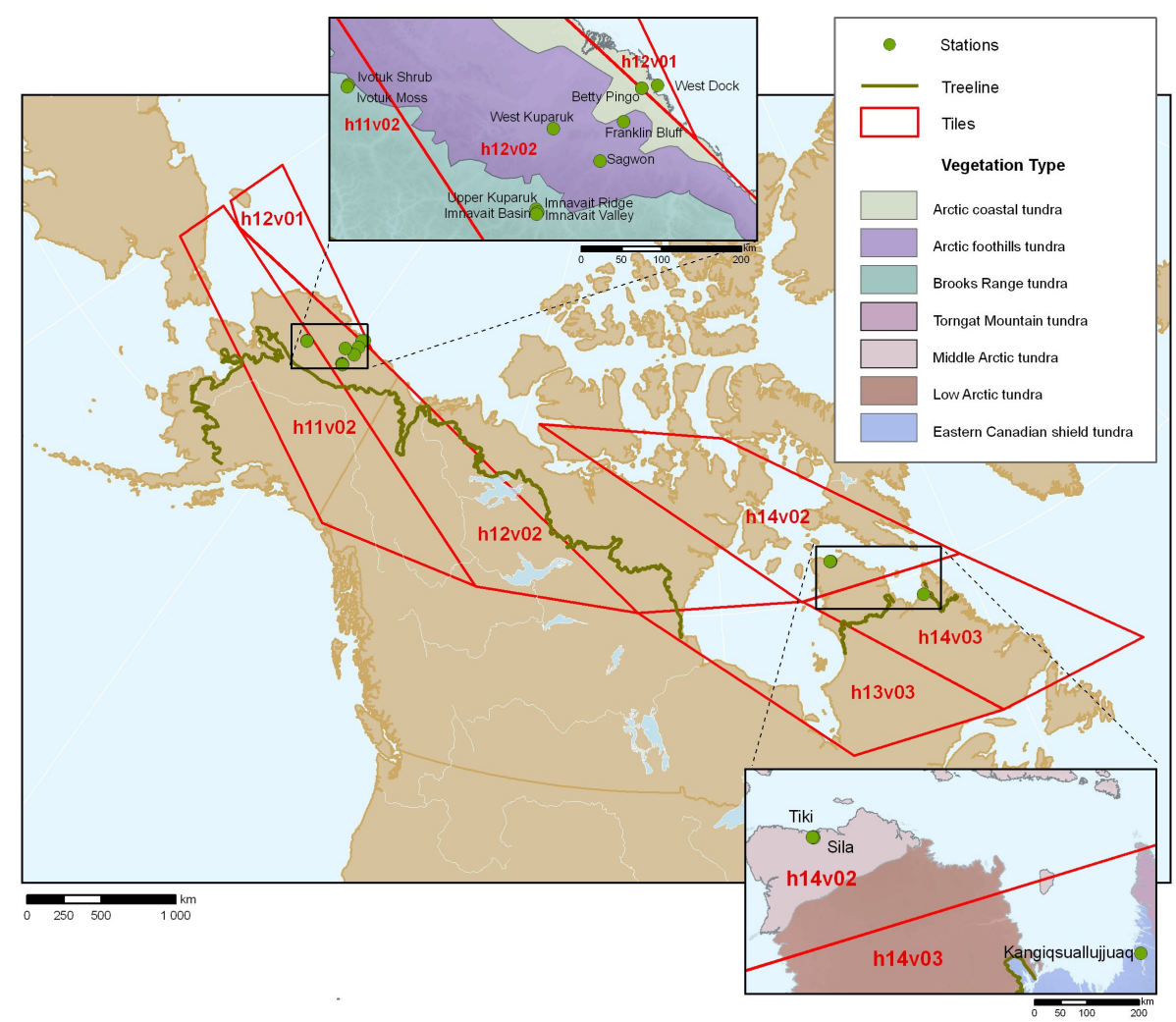

Fig. 1. Location of field sites and MODIS tiles for the North Slope of Alaska and Nunavik (Québec) in a Lambert conic conformal projection.

\subsubsection{Stations on the North Slope of Alaska, USA}

Sites in the Kuparuk River watershed and adjacent areas extend along a $250 \mathrm{~km}$ north-south ecological transect (Fig. 1). The transect is characterized from north to south by moss and lichen vegetation at Betty Pingo (northernmost station), herbaceous vegetation at Franklin Bluff and shrub vegetation at Sagwon (southernmost station). All data from the Alaskan stations were retrieved from the Water and Environmental Research Center (WERC) website ${ }^{2}$ where an in-depth description of the sites can be found. In addition, Jia and Epstein. (2004) provide a general description of the Alaska North Slope region in which the Greater Kuparuk River basin is located.

\subsubsection{GST and $T_{\text {air }}$ measurements at stations}

The GST is measured at a depth of $3-5 \mathrm{~cm}$ in the ground (for the thermistor to be protected from bad weather and direct solar radiation). Six of the ground-based stations were equipped with data loggers measuring hourly ground temperatures (Sila, Tiki, Betty Pingo Upland, Betty Pingo Wetland, Franklin Bluff and Sagwon) while at Ivotuk moss soil temperatures were recorded every $3 \mathrm{~h}$. At West Kuparuk and Imnavait Basin only daily average temperatures were recorded.

\footnotetext{
${ }^{2}$ http://www.uaf.edu/water/
}

There were no GST data available at West Dock, Upper Kuparuk, Ivotuk Shrub, Salluit Airport (SalA), and Kuujjuaq (Table 1). $T_{\text {air }}$ was measured at $1-3 \mathrm{~m}$ above the ground for all stations, except at Betty Pingo Upland where it is not measured. When hourly measurements coincident with the time of MODIS data acquisitions were available, it was possible to compare the $T_{\text {air }}$ and GST measurements with those acquired at the time of Terra and Aqua overpasses above the stations.

\subsection{Location of MODIS pixels corresponding to the meteorological stations}

We assume that the LST values correspond to measurements of the $\sim 1 \mathrm{~km}^{2}$ pixel footprint, taking into account potential geolocation errors of up to $50 \mathrm{~m}$ for the center of the footprint and some variations in footprint area (Wan, 2007; MOD11 User guide). These small errors can contribute to lengthen somewhat the footprint at high latitudes where no Ground Control Points (GCPs) were tested (Wolfe et al., 2002). MODIS pixels centered on or located close to the meteorological stations were selected for temperature comparisons. The presence of water bodies of different sizes in the proximity of certain stations can result in a mixed MODIS pixel over a given station. For example, a $1 \mathrm{~km}^{2}$ pixel containing a water fraction larger than that of land can 
introduce some difficulties when comparing a satellite pixel with a measurement from the meteorological station which is located solely on land.

For meteorological stations located along the shore of water bodies that have an area greater than $1 \mathrm{~km}^{2}$ (West Dock, Franklin Bluff, Western Kuparuk, Imnavait Basin, Tiki, and Kangiqsuallujjuaq), two MODIS pixels, one which contains the geographic coordinates of the station (" 1 " is added after the station name) and another one within $2 \mathrm{~km}$ of the station (" 2 " is added after the station name), were chosen (Table 2).

For the Northern Québec sites, the water fraction within each MODIS pixel was determined using the Canada-wide $1 \mathrm{~km}$ water fraction data product from National Topographic Data Base Maps (NTDB) (Fernandes et al., 2002). This raster product gives a percentage for the fraction of water contained in each $1 \mathrm{~km}^{2}$ pixel. The surface category types were established using NTDB maps at the scale of 1/50000 and $1 / 250000$. "The majority of NTDB source maps was surveyed within the growing season (post snow melt) and should therefore be relatively unbiased during the growing season in the absence of drought or severe precipitation events"3. Only the open water category was retained for the determination of water fraction within each $1 \mathrm{~km}$ grid cell (i.e. humid zones, wetlands, and small ponds are excluded). Thus, one must keep in mind that the LST for some sites may be influenced by variations in surface wetness/moisture (seasonally and annually) even if the water fraction given in the NTDB raster product corresponds to $0 \%$. MODIS pixels corresponding to the coordinates of the stations Tiki, Sila and Salluit airport contained $100 \%, 9.7 \%$, and $0 \%$ of water, respectively. The pixel containing the Sila tower is called Sila1, the one that includes the Tiki station is referred to as Tikil and the one with Salluit airport station is called SalA1 (Table 2). The pixel named Tiki2 is situated one pixel south of Tiki1 and contains less water (17.5\%). At Kangiqsuallujjuaq, the pixel centered on the station has a water fraction value of $10.4 \%$ (Kangiq1). An adjacent pixel with $8.9 \%$ water coverage was chosen (Kangiq2) to test the reproducibility of measurements over similar terrain further away from the reference station. At Kuujjuaq, the pixel corresponding to the village coordinates had $0 \%$ water on the Water fraction map (site Kuujjuaq1). Unfortunately, it had no LST values recorded from 2000 to 2008 . Thus, two other pixels were chosen with also $0 \%$ of water. One is situated at the pixel on the left and down of the original position (Kuujjuaq2) whereas the second one is on the right (Kuujjuaq3).

A map of land surface types of the North Slope of Alaska was used as an aid for selecting pixels corresponding to stations located in the Greater Kuparuk River watershed. The map used is the Land-Cover Map of the North Slope of Alaska $^{3}$ which represents soil and vegetation types. Nine categories were found in this map; one of them corresponded

\footnotetext{
${ }^{3}$ This map is accessible via the NSIDC website: http://nsidc.org/data/arcss020.html
}

to "water". The map was derived from the classification of a mosaic of Landsat MSS images resampled at $100 \times 100 \mathrm{~m}$ spatial resolution. The Landsat images were acquired during the snow-free period. Water bodies could readily be identified and water fraction determined for each MODIS pixel (i.e. 100 Landsat pixels within one MODIS pixel). The water fraction, expressed in percent, was determined for each site: West Dock (WD1: 57.5\% -WD2: one pixel south with $28.1 \%$ water), Betty Pingo Upland (BPU1: $1.5 \%$ ) and Wetland (BPW1: 17.9\%), Upper Kuparuk (UK1: $2.2 \%$ ), West Kuparuk (WK1: no standing water; but as the vegetation is very wet, another pixel with a lesser percentage of wet vegetation was taken - WK2: one pixel north with $7.2 \%$ water). For the same reason, two pixels were selected for Franklin Bluff (FB1 and FB2) even though both of them had $0 \%$ water fraction reported (Table 2).

\subsection{Statistics used for comparisons between LST, and GST and $T_{\text {air }}$ measurements at meteorological stations}

Three statistical parameters were computed to compare LST with GST and $T_{\text {air }}$ from meteorological stations: the Pearson correlation coefficient $(R)$, the mean difference (MD) and the standard deviation of the MD (SD). $R$ was used as a measure of the temporal coherence (co-variation in time) between LST and station temperature measurements (GST and $\left.T_{\text {air }}\right)$. The mean difference $\left(T_{\text {air }}-\right.$ LST or GST - LST) was used as a measure of the difference between the two sets of data. It is equal to zero when the mean LST is equal to the $T_{\text {air }}$ mean or the GST mean. If the MD is negative, the mean LST is larger (warmer) than the mean $T_{\text {air }}$ or GST. Inversely, if the MD is positive, then the mean LST is lower than the mean $T_{\text {air }}$ or GST. The SD was used to verify how large the variability around the mean MD was. It is important to note prior to analyzing the results that the LSTs are being verified/compared, not validated, against the temperature measurements from the meteorological stations. Strictly defined, validation would require the deployment of thermal infrared radiometers (TIR) within the $1 \mathrm{~km}^{2}$ resolution of the MODIS pixels that encompass the field sites.

The two overpass times for each satellite allow for the possibility of four temperature measurements per day, under clear-sky conditions. Each MODIS LST data series (AquaLST-day, Aqua-LST-night, Terra-LST-day, and Terra-LSTnight) was compared with GST and $T_{\text {air }}$ taken at each station when possible within the hour of the satellite overpass. To avoid any confusion, overpass hours corresponding to the LST-Day are called daytime, the ones corresponding to LSTNight are nighttime, and the mean of LST-Day and LSTNight is considered as the daily average. At least one measurement of LST-Day (either from Aqua or Terra) and one measurement of LST-Night (either from Aqua or Terra), were required to calculate a daily average for LST, otherwise there was no daily value calculated for this day. Thus, in some 
Table 2. Correspondence between stations and MODIS pixels used for comparison. Pixel description refers to the coordinates of the station within the tile and the NTDB superimposed into a Geographical Information System. \% of water corresponds to the NTDB value, if it is small we kept the pixel including the station coordinates. When the percent of water is high, we took the closest pixel with less $\%$ of water. Example: For BPW, the twelve closest pixels to the station had more than $17.9 \%$ of water. As a result, we kept the pixel including the station coordinates.

\begin{tabular}{|c|c|c|c|c|c|c|c|}
\hline \multirow[t]{2}{*}{ Station Name } & & \multirow{2}{*}{$\begin{array}{l}\text { Time period of station } \\
\text { measurements }\end{array}$} & \multirow[t]{2}{*}{ Pixel Name } & \multicolumn{2}{|c|}{ Pixel center coordinate } & \multirow[t]{2}{*}{ MODIS tile } & \multirow[t]{2}{*}{ Pixel position description } \\
\hline & & & & Latitude $(\mathrm{N})$ & Longitude (W) & & \\
\hline \multicolumn{8}{|l|}{ Alaska } \\
\hline \multirow[t]{2}{*}{ West Dock } & Tair: & $03 / 02 / 2000$ to $29 / 10 / 2008$ & WD1 & $70^{\circ} 22^{\prime} 50^{\prime \prime}$ & $148^{\circ} 33^{\prime} 39^{\prime \prime}$ & h13v01 & Near the coast ( $57.5 \%$ water $)$ \\
\hline & & & WD2 & $70^{\circ} 22^{\prime} 20.33^{\prime \prime}$ & $148^{\circ} 34^{\prime} 16.24^{\prime \prime}$ & h13v01 & One pixel south of WD1 ( $28.1 \%$ water) \\
\hline Betty Bingo (upland) - GST & GST: & $01 / 01 / 2000$ to $19 / 10 / 2008$ & BPU1 & $70^{\circ} 16^{\prime} 46.3^{\prime \prime}$ & $148^{\circ} 53^{\prime} 44.5^{\prime \prime}$ & $\mathrm{h} 12 \mathrm{v} 01$ & One pixel of water ( $1.5 \%$ water), same pixel kept \\
\hline Betty Pingo (wetland) - Tair & Tair: & $01 / 01 / 2000$ to $31 / 12 / 2008$ & BPW1 & $70^{\circ} 16^{\prime} 46.7^{\prime \prime}$ & $148^{\circ} 53^{\prime} 46^{\prime \prime}$ & $\mathrm{h} 12 \mathrm{v} 01$ & $\begin{array}{l}\text { Twelve pixels of water around the station } \\
\text { (17.9\% water), same pixel kept }\end{array}$ \\
\hline \multirow{2}{*}{$\begin{array}{l}\text { Eastern Kuparuk } \\
\text { (Franklin Bluff) }\end{array}$} & Tair: & $01 / 01 / 2000$ to $31 / 12 / 2007$ & FB1 & $69^{\circ} 53^{\prime} 31.8^{\prime \prime}$ & $148^{\circ} 46^{\prime} 4.8^{\prime \prime}$ & $\mathrm{h} 12 \mathrm{v} 02$ & Close to a river ( $60 \%$ of wet graminoid) \\
\hline & GST: & $29 / 04 / 2001$ to $31 / 12 / 2007$ & FB2 & $69^{\circ} 53^{\prime} 27.12^{\prime \prime}$ & $148^{\circ} 46^{\prime} 59.95^{\prime \prime}$ & $\mathrm{h} 12 \mathrm{v} 02$ & One pixel east of $\mathrm{FrB} 1$ ( $50 \%$ of wet graminoid) \\
\hline \multirow{2}{*}{$\begin{array}{l}\text { Eastern Kuparuk } \\
\text { (Sagwon) }\end{array}$} & Tair: & $01 / 01 / 2000$ to $31 / 12 / 2008$ & SAG1 & $69^{\circ} 25^{\prime} 27.5^{\prime \prime}$ & $148^{\circ} 41^{\prime} 45.1^{\prime \prime}$ & $\mathrm{h} 12 \mathrm{v} 02$ & No water, same pixel kept \\
\hline & GST: & $01 / 01 / 2003$ to $28 / 12 / 2008$ & & & & & \\
\hline \multirow[t]{2}{*}{ West Kuparuk } & Tair: & $25 / 04 / 2000$ to $22 / 09 / 2008$ & WK1 & $69^{\circ} 25^{\prime} 34.3^{\prime \prime}$ & $150^{\circ} 20^{\prime} 25.3^{\prime \prime}$ & $\mathrm{h} 12 \mathrm{v} 02$ & No water, same pixel kept \\
\hline & GST: & $25 / 04 / 2000$ to $16 / 09 / 2008$ & WK2 & $69^{\circ} 26^{\prime} 09.62^{\prime \prime}$ & $150^{\circ} 19^{\prime} 47.70^{\prime \prime}$ & $\mathrm{h} 12 \mathrm{v} 02$ & One pixel north west of WK1 (7.2\% water) \\
\hline Upper Kuparuk & Tair: & $01 / 03 / 2000$ to $14 / 09 / 2008$ & UK1 & $68^{\circ} 38^{\prime} 24.56^{\prime \prime}$ & $149^{\circ} 24^{\prime} 23.4^{\prime \prime}$ & $\mathrm{h} 12 \mathrm{v} 02$ & One pixel of water ( $2 \%$ water), same pixel kept \\
\hline \multirow[t]{2}{*}{ Imnavait Basin } & Tair: & $01 / 01 / 2000$ to $31 / 12 / 2008$ & IB1 & $68^{\circ} 36^{\prime} 58.6^{\prime \prime}$ & $149^{\circ} 18^{\prime} 13^{\prime \prime}$ & $\mathrm{h} 12 \mathrm{v} 02$ & No water, same pixel kept \\
\hline & GST: & $01 / 01 / 2000$ to $25 / 10 / 2007$ & IB2 & $68^{\circ} 37^{\prime} 2.7^{\prime \prime}$ & $149^{\circ} 19^{\prime} 2.3^{\prime \prime}$ & $\mathrm{h} 12 \mathrm{v} 02$ & One pixel north west of IB1 (no water) \\
\hline Ivotuk Shrub & Tair: & $01 / 01 / 2000$ to $31 / 12 / 2004$ & IvShrb1 & $68^{\circ} 29^{\prime} 12^{\prime \prime}$ & $155^{\circ} 44^{\prime} 34^{\prime \prime}$ & $\mathrm{h} 12 \mathrm{v} 02$ & No water, same pixel kept \\
\hline Ivotuk Moss & Tair: & $01 / 01 / 2000$ to $31 / 12 / 2004$ & IvMoss1 & $68^{\circ} 28^{\prime} 49.2^{\prime \prime}$ & $150^{\circ} 44^{\prime} 42.6^{\prime \prime}$ & $\mathrm{h} 12 \mathrm{v} 02$ & No water, same pixel kept \\
\hline \multicolumn{8}{|l|}{ Québec } \\
\hline Sila & Tair/GST & $05 / 08 / 2002$ to $13 / 10 / 2003$ & Sila1 & $62^{\circ} 11^{\prime} 41.9^{\prime \prime}$ & $75^{\circ} 38^{\prime} 12.8^{\prime \prime}$ & $\mathrm{h} 14 \mathrm{v} 02$ & Near the coast (9.7\% water), same pixel kept \\
\hline \multirow[t]{2}{*}{ Tiki } & Tair/GST & $30 / 07 / 2002$ to $13 / 10 / 2003$ & Tiki1 & $62^{\circ} 12^{\prime} 14.1^{\prime \prime}$ & $75^{\circ} 41^{\prime} 11.6^{\prime \prime}$ & $\mathrm{h} 14 \mathrm{v} 02$ & In the water $(100 \%$ water $)$ \\
\hline & & & Tiki2 & & & $\mathrm{h} 14 \mathrm{v} 02$ & One pixel south of Tiki ( $17.5 \%$ water) \\
\hline Salluit airport & Tair: & $28 / 07 / 2002$ to $14 / 10 / 2007$ & SalA1 & $62^{\circ} 11^{\prime} 1.44^{\prime \prime}$ & $75^{\circ} 39^{\prime} 54.9^{\prime \prime}$ & $\mathrm{h} 14 \mathrm{v} 02$ & No water, same pixel kept \\
\hline \multirow[t]{2}{*}{ Kangiqsuallujjuaq } & Tair: & $05 / 06 / 2001$ to $02 / 11 / 2004$ & Kangiq1 & $58^{\circ} 41^{\prime} 28.2^{\prime \prime}$ & $65^{\circ} 55^{\prime} 23.16^{\prime \prime}$ & $\mathrm{h} 14 \mathrm{v} 03$ & Near the coast ( $10.4 \%$ water) \\
\hline & & & Kangiq2 & & & $\mathrm{h} 14 \mathrm{v} 03$ & One pixel right ( $8.9 \%$ water) \\
\hline \multirow[t]{3}{*}{ Kuujjuaq } & Tair: & $01 / 01 / 2000$ to $31 / 12 / 2008$ & Kuujjuaq1 & $58^{\circ} 06^{\prime} 31.62^{\prime \prime}$ & $68^{\circ} 24^{\prime} 42.44^{\prime \prime}$ & $\mathrm{h} 14 \mathrm{v} 03$ & This pixel containing the station had no LST values: \\
\hline & & & Kuujjuaq2 & & & $\mathrm{h} 14 \mathrm{v} 03$ & One pixel right and one down (no water) \\
\hline & & & Kuujjuaq3 & & & $\mathrm{h} 14 \mathrm{v} 03$ & One pixel left (no water) \\
\hline
\end{tabular}

1:pixel including station; 2 or 3 : other pixel.

cases, the mean daily LST was determined using the LSTDay retrieved by Aqua and the LST-Night obtained by Terra, and vice-versa. The intent was to have the maximum number of LST measurements per day, over a $24 \mathrm{~h}$ period, providing for the calculation of a mean daily temperature that closely approaches the mean daily temperature measured at the ground stations.

Firstly, hourly comparisons were made to allow a verification of the LST-day and the LST-night for Aqua and Terra separately. $R, \mathrm{MD}$ and $\mathrm{SD}$ values between each LST data series and the hourly temperatures at stations when available (14 pixels and 10 stations in Alaska, and 6 pixels and 4 stations in Québec for $T_{\text {air }} ; 5$ pixels and 4 stations in Alaska, and 2 pixels and 2 stations in Québec for GST, Tables 1 and 2), were calculated. Secondly, mean daily temperatures (from the previous stations for $T_{\text {air }}$; and 5 more pixels and 4 more stations with daily averages for GST, Tables 1 and 2) were compared with "daily" Terra and "daily" Aqua LSTs (average LST-day and LST-night) individually. Thirdly, the daily average temperatures were compared with the daily LSTs from Terra and Aqua averaged. The results from these three comparisons are showed on Figs. 2-4 and in Tables 5 and 7. Finally, comparisons were also made seasonally (snow- free and winter seasons) and on an annual basis (Fig. 5 and Table 6).

To estimate of first day and last day of snow presence on the ground in the two study areas, IMS (Interactive Multisensor Snow and Ice Mapping System) images of snow extent obtained from the National Snow and Ice Data Center (NSIDC) archive ftp site ${ }^{4}$ were examined. For the nine years of this study (2000-2008), the average last day of snow presence was 14 June in Alaska and 23 June in Northern Québec, while that of the first day of snow on the ground was 27 September in Alaska and 3 October in Québec.

All cited times are local times. As indicated in Table 3, the two satellites pass more frequently over Alaska between 10:00 and 12:00 LT and over Northern Québec between 11:00 and 13:00 LT. At their ascending overpasses (LSTDay), the sensors retrieve LSTs from the warmest hours of the day $(24 \mathrm{~h})$. During their descending overpasses (LSTNight), Aqua passes over Alaska between 00:00 and 02:00 and over Northern Québec between 02:00 and 03:00 (coldest hours of the day), while Terra passes over Alaska between 19:00 and 21:00 and over Northern Québec between 21:00

\footnotetext{
${ }^{4} \mathrm{ftp} / / /$ sidads.colorado.edu/pub/DATASETS/NOAA/G02156/ images/
} 

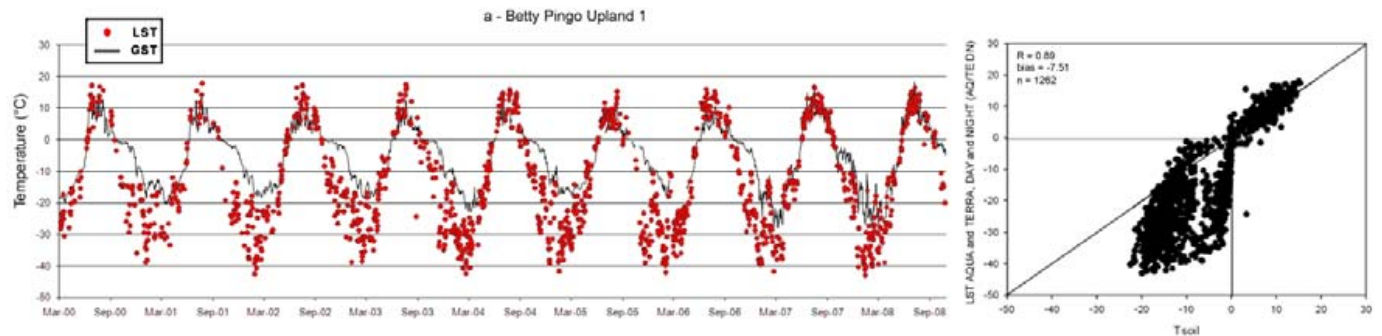

b- Frankinin Bluff 1
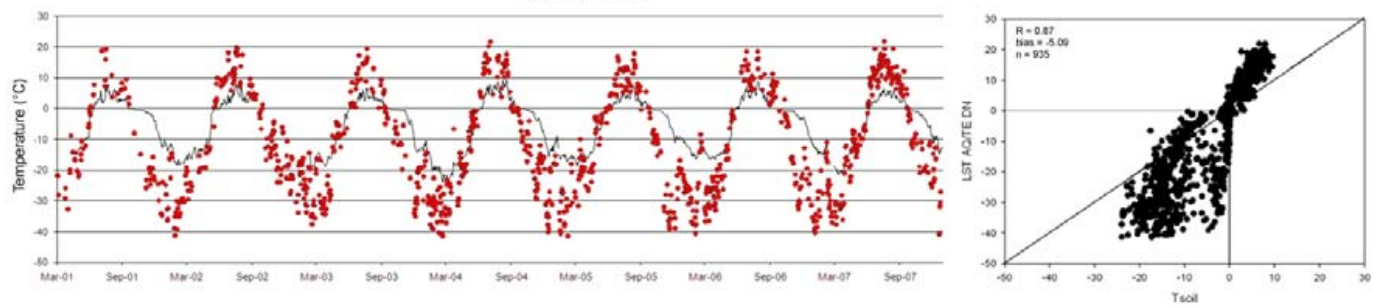

c- West Kuparuk 1
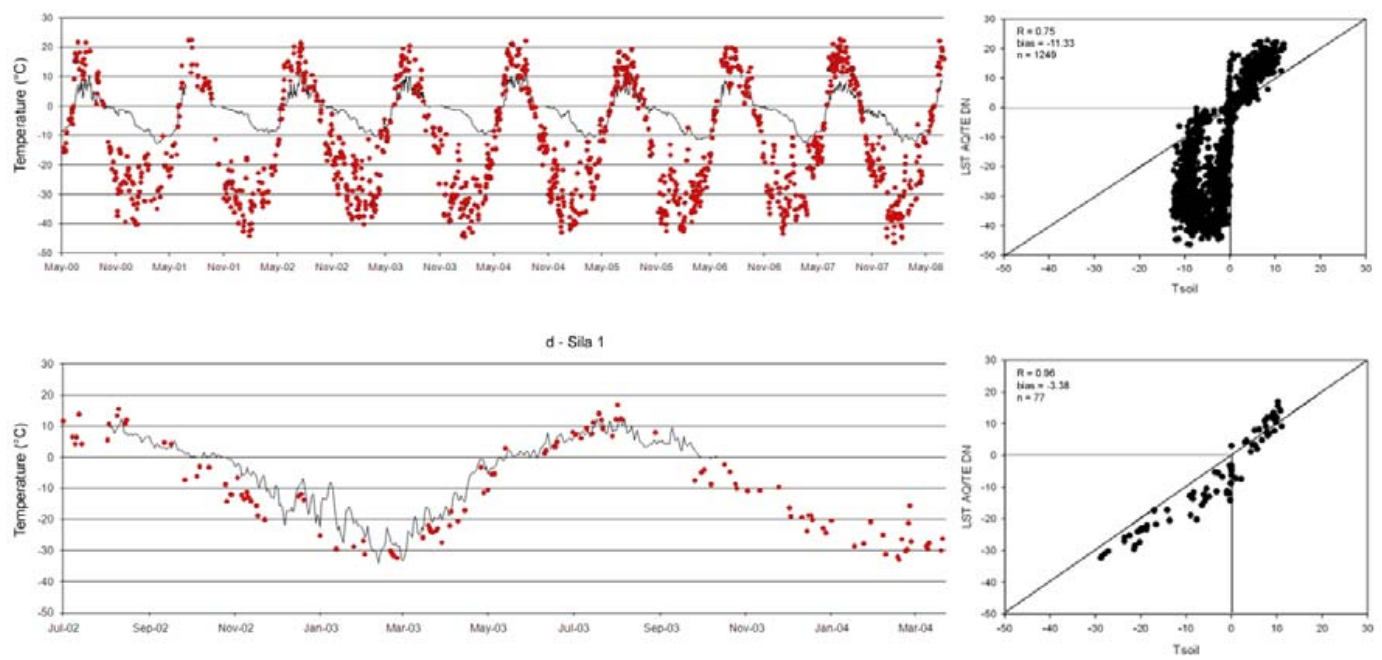

Fig. 2. Relation between mean daily MODIS LST (combined Terra and Aqua) and mean daily GST at (a) Betty Pingo Upland (BPU1), (b) Franklin Bluff (FB1), (c) Western Kuparuk (WK1), and (d) Sila (Sila1).

and 22:00. In reality, overpass times are not on the hour. As a result, the satellite overpass times were rounded to the nearest full hour (within $30 \mathrm{~min}$ ) to simplify the comparison with station measurements. For example, satellite data acquired between 10:30 and 11:30 are used for comparison with hourly station measurements at 11:00.

\section{Results}

LSTs are not continuously retrieved from MODIS so that many consecutive days are without values. This is due to lasting cloudy conditions over the study areas (Table 4). For the period when only Terra was in orbit (2000-2001), cloudless days accounted for only 5 to $19 \%$ (average of $12 \%$ ) and 23 to $32 \%$ (average of $28 \%$ ) of the MODIS observations over
Northern Québec and Alaska, respectively, depending on the location of the meteorological stations. When MODIS observations from both Terra and Aqua became available, starting in 2002, the percentage of cloudless days increased to $20 \%$ on average over the Québec stations and about $46 \%$ over the stations located in Alaska. On average, only 33 days of daily LST values were available during each snow-free season from 2000 to 2008 over Alaska and 22 over Québec. During the snow cover period, 99 such days were retrieved on average over Alaska and 44 over Québec. This low count is explained by the high cloudiness over the Arctic, more so in summer than in winter (Eastman and al., 2010). The low count in each individual season limits the use of the LST for calculating directly freezing and thawing indices or n-factors. Hachem et al. (2009) used a simple sinusoidal model to fill 
Table 3. Frequency of Aqua and Terra satellite overpasses within different hours above the field stations during the period of study (20002008). The most frequent overpass times for the different stations are given in bold.

\begin{tabular}{|c|c|c|c|c|c|c|c|c|c|c|c|c|c|c|c|c|c|c|c|c|c|c|c|c|}
\hline \multirow[b]{3}{*}{$\begin{array}{l}\text { Pixels Over } \\
\text { Alaska }\end{array}$} & \multicolumn{12}{|c|}{ Aqua overpass hours } & \multicolumn{12}{|c|}{ Terra overpass hours } \\
\hline & \multicolumn{6}{|c|}{ Day Time (LST-Day) } & \multicolumn{6}{|c|}{ Night time (LST-Night) } & \multicolumn{6}{|c|}{ Day time (LST-Day) } & \multicolumn{6}{|c|}{ Night time (LST-Night) } \\
\hline & 9 & 10 & 11 & 12 & 13 & 14 & 0 & 1 & 2 & 3 & 4 & 5 & 10 & 11 & 12 & 13 & 14 & 15 & 18 & 19 & 20 & 21 & 22 & 23 \\
\hline WD1 & 0.13 & 0.25 & 0.21 & 0.26 & 0.10 & 0.05 & 0.13 & 0.35 & 0.18 & 0.19 & 0.11 & 0.05 & 0.07 & 0.29 & 0.25 & 0.11 & 0.10 & 0.18 & 0.09 & 0.25 & 0.28 & 0.28 & 0.09 & 0.02 \\
\hline WD2 & 0.13 & 0.25 & 0.22 & 0.27 & 0.09 & 0.05 & 0.13 & 0.34 & 0.18 & 0.18 & 0.12 & 0.04 & 0.07 & 0.28 & 0.26 & 0.11 & 0.09 & 0.17 & 0.09 & 0.25 & 0.29 & 0.28 & 0.08 & 0.02 \\
\hline BPU1 & 0.13 & 0.30 & 0.20 & 0.21 & 0.11 & 0.04 & 0.14 & 0.36 & 0.17 & 0.18 & 0.11 & 0.04 & 0.07 & 0.27 & 0.23 & 0.10 & 0.13 & 0.18 & 0.10 & 0.25 & 0.29 & 0.27 & 0.08 & 0.01 \\
\hline BPW1 & 0.13 & 0.30 & 0.20 & 0.21 & 0.11 & 0.04 & 0.14 & 0.36 & 0.18 & 0.18 & 0.10 & 0.04 & 0.07 & 0.27 & 0.23 & 0.10 & 0.13 & 0.19 & 0.10 & 0.25 & 0.29 & 0.27 & 0.08 & 0.01 \\
\hline FB1 & 0.10 & 0.28 & 0.23 & 0.25 & 0.10 & 0.03 & 0.17 & 0.38 & 0.17 & 0.16 & 0.08 & 0.03 & 0.06 & 0.32 & 0.24 & 0.11 & 0.13 & 0.14 & 0.08 & 0.26 & 0.27 & 0.26 & 0.11 & 0.02 \\
\hline FB2 & 0.10 & 0.30 & 0.22 & 0.23 & 0.11 & 0.04 & 0.16 & 0.37 & 0.17 & 0.17 & 0.10 & 0.04 & 0.06 & 0.33 & 0.22 & 0.09 & 0.14 & 0.15 & 0.08 & 0.26 & 0.28 & 0.26 & 0.10 & 0.02 \\
\hline SAG1 & 0.06 & 0.30 & 0.29 & 0.22 & 0.09 & 0.04 & 0.18 & 0.39 & 0.16 & 0.15 & 0.08 & 0.03 & 0.07 & 0.35 & 0.24 & 0.10 & 0.13 & 0.11 & 0.05 & 0.29 & 0.30 & 0.25 & 0.10 & 0.02 \\
\hline WK1 & 0.06 & 0.29 & 0.28 & 0.20 & 0.10 & 0.06 & 0.19 & 0.40 & 0.15 & 0.15 & 0.07 & 0.03 & 0.07 & 0.35 & 0.20 & 0.10 & 0.17 & 0.12 & 0.06 & 0.30 & 0.30 & 0.24 & 0.09 & 0.01 \\
\hline WK2 & 0.07 & 0.29 & 0.27 & 0.21 & 0.11 & 0.06 & 0.18 & 0.40 & 0.15 & 0.16 & 0.07 & 0.04 & 0.07 & 0.35 & 0.20 & 0.09 & 0.16 & 0.12 & 0.06 & 0.31 & 0.29 & 0.24 & 0.09 & 0.01 \\
\hline UK1 & - & 0.30 & 0.35 & 0.22 & 0.09 & 0.04 & 0.18 & 0.41 & 0.15 & 0.16 & 0.08 & 0.02 & 0.11 & 0.44 & 0.23 & 0.08 & 0.11 & 0.03 & - & 0.27 & 0.36 & 0.26 & 0.10 & 0.02 \\
\hline IB1 & - & 0.30 & 0.36 & 0.21 & 0.10 & 0.02 & 0.17 & 0.41 & 0.16 & 0.16 & 0.08 & 0.02 & 0.10 & 0.44 & 0.23 & 0.08 & 0.12 & 0.03 & - & 0.27 & 0.37 & 0.25 & 0.09 & 0.02 \\
\hline IB2 & - & 0.31 & 0.37 & 0.20 & 0.10 & 0.02 & 0.16 & 0.40 & 0.17 & 0.16 & 0.08 & 0.02 & 0.10 & 0.43 & 0.25 & 0.09 & 0.11 & 0.03 & - & 0.26 & 0.37 & 0.26 & 0.09 & 0.02 \\
\hline IvShrb1 & - & 0.25 & 0.29 & 0.20 & 0.11 & 0.15 & 0.18 & 0.40 & 0.16 & 0.16 & 0.07 & 0.03 & 0.09 & 0.34 & 0.24 & 0.08 & 0.22 & 0.03 & - & 0.22 & 0.34 & 0.29 & 0.12 & 0.03 \\
\hline IvMoss 1 & - & 0.25 & 0.30 & 0.20 & 0.10 & 0.15 & 0.18 & 0.41 & 0.16 & 0.16 & 0.06 & 0.03 & 0.08 & 0.34 & 0.24 & 0.08 & 0.23 & 0.03 & - & 0.21 & 0.34 & 0.31 & 0.12 & 0.02 \\
\hline $\begin{array}{l}\text { Pixels Over } \\
\text { Québec }\end{array}$ & 9 & 10 & 11 & 12 & 13 & 14 & 0 & 1 & 2 & 3 & 4 & 5 & 10 & 11 & 12 & 13 & 14 & 15 & 18 & 19 & 20 & 21 & 22 & 23 \\
\hline Sila1 & - & - & 0.19 & 0.40 & 0.36 & 0.06 & 0.09 & 0.16 & 0.28 & 0.40 & 0.07 & - & 0.07 & 0.41 & 0.41 & 0.12 & - & - & - & - & 0.15 & 0.47 & 0.33 & 0.05 \\
\hline Tiki2 & - & - & 0.18 & 0.38 & 0.39 & 0.06 & 0.09 & 0.15 & 0.29 & 0.38 & 0.08 & - & 0.06 & 0.41 & 0.40 & 0.13 & - & - & - & - & 0.15 & 0.45 & 0.34 & 0.06 \\
\hline SalA1 & - & - & 0.18 & 0.49 & 0.37 & 0.06 & 0.05 & 0.12 & 0.36 & 0.38 & 0.09 & - & 0.07 & 0.41 & 0.39 & 0.12 & - & - & - & - & 0.15 & 0.46 & 0.34 & 0.06 \\
\hline Kangiq1 & - & - & 0.07 & 0.38 & 0.43 & 0.12 & 0.07 & 0.12 & 0.35 & 0.37 & 0.08 & - & 0.09 & 0.44 & 0.37 & 0.10 & - & - & - & - & 0.09 & 0.45 & 0.38 & 0.08 \\
\hline Kangiq2 & - & - & 0.08 & 0.38 & 0.43 & 0.11 & 0.07 & 0.13 & 0.37 & 0.35 & 0.07 & - & 0.09 & 0.44 & 0.37 & 0.10 & - & - & - & - & 0.10 & 0.44 & 0.38 & 0.08 \\
\hline Kujjuaq2 & - & - & 0.06 & 0.38 & 0.47 & 0.09 & 0.10 & 0.19 & 0.36 & 0.28 & 0.07 & - & 0.08 & 0.49 & 0.36 & 0.07 & - & - & - & - & 0.11 & 0.44 & 0.36 & 0.09 \\
\hline Kujjuaq3 & - & - & 0.05 & 0.37 & 0.48 & 0.10 & 0.07 & 0.16 & 0.41 & 0.31 & 0.05 & - & 0.09 & 0.48 & 0.35 & 0.07 & - & - & - & - & 0.11 & 0.46 & 0.34 & 0.09 \\
\hline
\end{tabular}

in gaps for the small number of daily LST values. Another approach to compensate for this difficulty would be to add data from other sensors (e.g. AMSRE for the snow free period) or to fill data gaps with data from reanalyzes.

\subsection{Ground surface temperature}

\subsubsection{Comparison of daytime, nighttime and daily mean GST with LST for Aqua and Terra overpasses separately on an annual basis}

When examining the data on an annual basis, daytime LST values over Sila and Tiki (Québec) are well correlated with hourly GST readings $(R$ is 0.94 with Aqua and 0.95 with Terra) and MD is small (around $-1{ }^{\circ} \mathrm{C}$ ) but with a high variability (SD values above $7^{\circ} \mathrm{C}$ ) (Table 5). The correlation is somewhat weaker between LST and GST during nighttime than during daytime. The $R(0.93)$ is still high but the MD is large $\left(7.7^{\circ} \mathrm{C}\right.$ with Aqua and $7.2^{\circ} \mathrm{C}$ with Terra) for a smaller SD. It reveals that the LSTs retrieved during daytime are closer to the GSTs than during nighttime with LSTs only $1^{\circ} \mathrm{C}$ higher than GSTs, but the high variability shows that LSTs are very variable around this $1^{\circ} \mathrm{C}$ (from $-8^{\circ} \mathrm{C}$ to $+7^{\circ} \mathrm{C}$ ). The LSTs during nighttime are $7^{\circ} \mathrm{C}$ lower than the GSTs with a variability around $4-5^{\circ} \mathrm{C}$, ranging from around $-13^{\circ} \mathrm{C}$ to $-2^{\circ} \mathrm{Cbelow}$ the GST values. For Québec, the values are quite identical for Aqua and Terra in daytime and nighttime separately, which suggests that a com- bination by averaging Aqua and Terra LST measurements could only help in reaching a greater number of LSTs. In Alaska, during daytime, only a good agreement $(R=0.85$ with Aqua-Day and $R=0.83$ with Terra-Day) with a large offset $\left(4.4^{\circ} \mathrm{C}<\mathrm{MD}<5.1^{\circ} \mathrm{C}\right)$ and a very large $\mathrm{SD}\left(>11^{\circ} \mathrm{C}\right)$ is found. At nighttime, the correlations are similar to those of daytime but MDs are larger and SDs lower (Table 5). It shows that at nighttime, problems appear that do not exist during daytime (Ackerman et al., 1998). Comparing data acquired within the same hour (not shown in tables) indicates that 13:00 and 14:00 $\mathrm{h}$ are the hours at which the mean differences between LST and GST are the smallest and correlations highest, independently of the station in Alaska, while it is at 12:00 h for the Québec stations.

At both the Québec and Alaska stations, the daytime comparisons show smaller MD than the nighttime ones, and the $\mathrm{SD}$ values are larger at daytime. Despite the good correlation, which indicates that the LST-Day and LST-Night values from Aqua and Terra oscillate in the same phase as the GST, the satellite-derived values are far in magnitude from the GST values (Fig. 2). The LST-day and the LST-night from Terra compared separately with the ones from Aqua, show that Aqua and Terra are close to each other for all stations over the entire study period, despite the different overpass times of the two satellites. When averaging the two LSTs (LST-Day and LST-Night) in Québec, the correlation turns out higher between GST and LST than with the separate daytime and nighttime $(R$-Daytime $=0.95, R$-Nighttime $=0.92$ 
Table 4. Number of days (percentage) with clear-sky MODIS LST measurements (2000-2008).

\begin{tabular}{lccccccccc}
\hline Pixel Name & 2000 & 2001 & 2002 & 2003 & 2004 & 2005 & 2006 & 2007 & 2008 \\
\hline \multicolumn{7}{c}{ Alaska } \\
\hline WD1 & - & - & $26 \%$ & $33 \%$ & $40 \%$ & $36 \%$ & $31 \%$ & $38 \%$ & $36 \%$ \\
WD2 & - & - & $29 \%$ & $34 \%$ & $41 \%$ & $39 \%$ & $32 \%$ & $36 \%$ & $36 \%$ \\
BPW1 & $23 \%$ & $24 \%$ & $37 \%$ & $41 \%$ & $54 \%$ & $50 \%$ & $47 \%$ & $49 \%$ & $44 \%$ \\
FB1 & $27 \%$ & $24 \%$ & $39 \%$ & $40 \%$ & $52 \%$ & $40 \%$ & $43 \%$ & $53 \%$ & $41 \%$ \\
FB2 & $27 \%$ & $27 \%$ & $39 \%$ & $42 \%$ & $53 \%$ & $39 \%$ & $43 \%$ & $54 \%$ & $40 \%$ \\
SAG1 & $26 \%$ & $31 \%$ & $42 \%$ & $44 \%$ & $53 \%$ & $48 \%$ & $45 \%$ & $58 \%$ & $41 \%$ \\
WK1 & $27 \%$ & $28 \%$ & $38 \%$ & $43 \%$ & $53 \%$ & $43 \%$ & $44 \%$ & $56 \%$ & $43 \%$ \\
WK2 & $26 \%$ & $29 \%$ & $39 \%$ & $45 \%$ & $53 \%$ & $43 \%$ & $46 \%$ & $56 \%$ & $44 \%$ \\
UK1 & $31 \%$ & $32 \%$ & $38 \%$ & $46 \%$ & $53 \%$ & $51 \%$ & $47 \%$ & $58 \%$ & $48 \%$ \\
IB1 & $32 \%$ & $32 \%$ & $35 \%$ & $45 \%$ & $54 \%$ & $54 \%$ & $43 \%$ & $59 \%$ & $48 \%$ \\
IB2 & $33 \%$ & $33 \%$ & $37 \%$ & $46 \%$ & $53 \%$ & $53 \%$ & $45 \%$ & $61 \%$ & $48 \%$ \\
IvShrb1 & $25 \%$ & $27 \%$ & $42 \%$ & $44 \$$ & $50 \%$ & $51 \%$ & $41 \%$ & $55 \%$ & $44 \%$ \\
IvMoss1 & $25 \%$ & $27 \%$ & $41 \%$ & $44 \%$ & $63 \%$ & $65 \%$ & $54 \%$ & $69 \%$ & $60 \%$ \\
\hline & & & 7 & Québec & & & & \\
\hline Sila1 & - & - & $15 \%$ & $18 \%$ & $17 \%$ & $17 \%$ & $19 \%$ & $19 \%$ & $21 \%$ \\
Tiki2 & - & - & $15 \%$ & $18 \%$ & $18 \%$ & $18 \%$ & $22 \%$ & $21 \%$ & $22 \%$ \\
SalA1 & - & - & $17 \%$ & $19 \%$ & $18 \%$ & $16 \%$ & $22 \%$ & $21 \%$ & $23 \%$ \\
Kangiq1 & - & $16 \%$ & $14 \%$ & $17 \%$ & $19 \%$ & $22 \%$ & $20 \%$ & $16 \%$ & $26 \%$ \\
Kangiq2 & - & $16 \%$ & $16 \%$ & $17 \%$ & $18 \%$ & $21 \%$ & $19 \%$ & $14 \%$ & $24 \%$ \\
Kujjuaq2 & $10 \%$ & $19 \%$ & $21 \%$ & $30 \%$ & $28 \%$ & $33 \%$ & $33 \%$ & $28 \%$ & $40 \%$ \\
Kujjuaq3 & $5 \%$ & $9 \%$ & $13 \%$ & $16 \%$ & $14 \%$ & $15 \%$ & $15 \%$ & $14 \%$ & $18 \%$ \\
\hline
\end{tabular}

and $R$-Daily $=0.96)$. The mean daily $\mathrm{MD}\left(3.1^{\circ} \mathrm{C}\right)$ is situated in-between the MDs from daytime $\left(-0.3^{\circ} \mathrm{C}\right)$ and nighttime $\left(7.7^{\circ} \mathrm{C}\right)$ and the mean daily $\mathrm{SD}\left(4.5^{\circ} \mathrm{C}\right)$ is also lower ( $7.4^{\circ} \mathrm{C}$ for daytime, $4.8^{\circ} \mathrm{C}$ for nighttime). Calculation of the mean daily LST can therefore be seen as an improvement over the separate daytime and nighttime values for Québec. In Alaska, on the other hand, the correlation is more moderate $(R=0.84)$, and the daily mean $\mathrm{MD}\left(7.8^{\circ} \mathrm{C}\right)$ and $\mathrm{SD}$ $\left(10.9^{\circ} \mathrm{C}\right)$ values are high; LST measurements during daytime and nighttime have the same order of difference with GST.

When daily mean LST and GST values are plotted against time (Fig. 2), a similar annual oscillation appears but the scatter graphs (Fig. 2) show a larger spread for temperatures below $0^{\circ} \mathrm{C}$ than above $0^{\circ} \mathrm{C}$, with LSTs being much colder (minimum close to $-50^{\circ} \mathrm{C}$ ) than GST $\left(-20^{\circ} \mathrm{C}\right.$ for BPU1 and $\mathrm{FrB} 1 ;-10^{\circ} \mathrm{C}$ for $\left.\mathrm{Wk} 1\right)$. This difference in wintertime does not appear at Sila1. In the positive temperature portion of the graph, the correlation looks better with a positive deviation (LST $>$ GST) from the 1:1 relation line. Also numerous GSTs are found around $0{ }^{\circ} \mathrm{C}$ when LSTs are very low $\left(-40^{\circ} \mathrm{C}\right.$ at $\mathrm{WK} 1,-10^{\circ} \mathrm{C}$ at Sila 1$)$ or positive $\left(+5^{\circ} \mathrm{C}\right.$ at Sila1, $+10^{\circ} \mathrm{C}$ at BPU1 and FrB 1 , and up to $+20^{\circ} \mathrm{C}$ at WK1), which corresponds to $0^{\circ} \mathrm{C}$ September dates at these stations. Overall, regionally, the relation between GST and LST is stronger for the Québec stations than the Alaskan stations.

\subsubsection{Comparison of daily mean GST with LST for Terra and Aqua combined during the snow free and snow cover periods}

Table 6 presents results of the comparison between GST and LST for each station for the complete year and for the snow free and snow covered periods separately. The snow free period shows a higher correlation than the snow cover period. The MD is negative $\left(-1\right.$ to $\left.-7^{\circ} \mathrm{C}\right)$ during the snow free period, which means that the LST values are higher than the GST during this period, and positive during the snow cover period $\left(5\right.$ to $\left.17^{\circ} \mathrm{C}\right)$, indicating that the LST values are lower during this period. SD is not very large (around $4{ }^{\circ} \mathrm{C}$ ) during the snow free period in comparison with the snow cover period (around $6^{\circ} \mathrm{C}$ ). This shows that the LST are close to the GST values only during the snow free period with a tendency to be $2{ }^{\circ} \mathrm{C}$ higher in general. Yet, for some Alaskan stations, LSTs are always higher (Franklin Bluff, Western Kuparuk and Ivotuk Moss). The Québec stations (Sila and Tiki) respond similarly to the Alaskan stations during the snow free period but yield a better correlation during the snow cover period. 
Table 5. Mean Difference (MD), Standard Deviation (SD) and Correlation $(R)$ between GST and LST for daytime, nighttime and daily average from Aqua and Terra separately, and Aqua/Terra combined.

\begin{tabular}{|c|c|c|c|c|c|}
\hline & & & Daytime mean & Nighttime mean & Daily mean \\
\hline \multirow{9}{*}{ Alaska (Ak) } & \multirow{3}{*}{ Terra } & MD & 4.4 & 8.0 & 6.9 \\
\hline & & $\mathrm{SD}$ & 11.8 & 9.3 & 11.5 \\
\hline & & $R$ & 0.83 & 0.84 & 0.84 \\
\hline & \multirow{3}{*}{ Aqua } & MD & 5.1 & 9.8 & 9.0 \\
\hline & & $\mathrm{SD}$ & 11.3 & 8.2 & 10.6 \\
\hline & & $R$ & 0.85 & 0.85 & 0.84 \\
\hline & \multirow{3}{*}{ Terra/Aqua } & MD & 4.9 & 8.6 & 7.8 \\
\hline & & $\mathrm{SD}$ & 11.4 & 8.7 & 10.9 \\
\hline & & $R$ & 0.84 & 0.85 & 0.84 \\
\hline \multirow{9}{*}{ Québec (Qc) } & \multirow{3}{*}{ Terra } & MD & -0.7 & 7.2 & 3.4 \\
\hline & & SD & 7.8 & 4.2 & 4.6 \\
\hline & & $R$ & 0.95 & 0.93 & 0.95 \\
\hline & \multirow{3}{*}{ Aqua } & MD & -0.6 & 7.7 & 2.7 \\
\hline & & SD & 7.5 & 4.8 & 4.5 \\
\hline & & $R$ & 0.94 & 0.93 & 0.97 \\
\hline & \multirow{3}{*}{ Terra/Aqua } & MD & -0.3 & 7.7 & 3.1 \\
\hline & & SD & 7.4 & 4.8 & 4.5 \\
\hline & & $R$ & 0.95 & 0.92 & 0.96 \\
\hline \multirow{3}{*}{ Ak and Qc } & \multirow{3}{*}{ Terra/Aqua } & MD & 2.3 & 8.2 & 5.4 \\
\hline & & SD & 9.4 & 6.7 & 7.7 \\
\hline & & $R$ & 0.89 & 0.88 & 0.90 \\
\hline
\end{tabular}

Table 6. Mean Difference (MD), Standard Deviation (SD) and Correlation $(R)$ between GST and LST during complete year, snow free and snow cover periods for Aqua/Terra combined.

\begin{tabular}{lcccccccccccc}
\hline GST-LST & \multicolumn{3}{c}{ Complete years } & \multicolumn{3}{c}{ Snow free period } & \multicolumn{3}{c}{ Snow cover period } \\
\hline Stations & $n$ & $R$ & MD & SD & $n$ & $R$ & MD & SD & $n$ & $R$ & MD & SD \\
\hline BPU1 & 1262 & 0.89 & 7.5 & 8.5 & 311 & 0.74 & -1.1 & 3.6 & 947 & 0.70 & 10.3 & 7.7 \\
BPW1 & 1263 & 0.86 & 8.6 & 9.4 & 311 & 0.81 & -0.9 & 3.1 & 948 & 0.59 & 11.7 & 8.6 \\
FB1 & 935 & 0.87 & 5.1 & 10.5 & 265 & 0.79 & -5.9 & 4.2 & 666 & 0.67 & 9.4 & 8.9 \\
FB2 & 955 & 0.86 & 5.5 & 10.9 & 282 & 0.81 & -5.9 & 4.4 & 668 & 0.65 & 10.3 & 9.2 \\
SAG1 & 1014 & 0.95 & 4.7 & 7.2 & 263 & 0.90 & -2.5 & 3.1 & 748 & 0.88 & 7.2 & 6.5 \\
WK1 & 1242 & 0.75 & 11.3 & 14.7 & 317 & 0.83 & -5.6 & 4.6 & 922 & 0.35 & 17.1 & 12.2 \\
WK2 & 1263 & 0.75 & 11.4 & 14.6 & 316 & 0.83 & -5.6 & 4.7 & 943 & 0.36 & 17.0 & 12.2 \\
IB1 & 1066 & 0.90 & 8.3 & 9.6 & 262 & 0.88 & -1.5 & 3.7 & 802 & 0.78 & 11.4 & 8.6 \\
IB2 & 1096 & 0.90 & 7.7 & 9.2 & 278 & 0.87 & -1.2 & 3.9 & 815 & 0.78 & 10.7 & 8.5 \\
IvMoss1 & 518 & 0.70 & 7.8 & 14.3 & 153 & 0.64 & -6.6 & 6.0 & 364 & 0.46 & 13.8 & 12.2 \\
\hline Alaska Stations & 1061 & 0.84 & 7.8 & 10.9 & 276 & 0.81 & -3.7 & 4.1 & 782 & 0.62 & 11.9 & 9.5 \\
\hline Sila1 & 77 & 0.96 & 3.4 & 4.4 & 24 & 0.88 & -0.6 & 3.9 & 53 & 0.95 & 5.2 & 3.3 \\
Tiki2 & 72 & 0.96 & 2.8 & 4.5 & 26 & 0.70 & -0.8 & 3.9 & 46 & 0.95 & 4.9 & 3.3 \\
\hline Québec Stations & 75 & 0.96 & 3.1 & 4.5 & 25 & 0.79 & -0.7 & 3.9 & 50 & 0.95 & 5.0 & 3.3 \\
\hline All Stations & 568 & 0.90 & 5.4 & 7.7 & 150 & 0.80 & -2.2 & 4.0 & 416 & 0.79 & 8.5 & 6.4 \\
\hline
\end{tabular}


Mean Aqua and Terra LST-Day

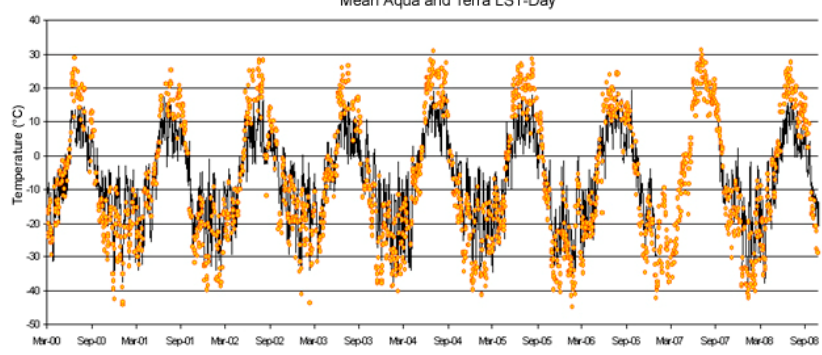

Mean Aqua and Terra LST-Night

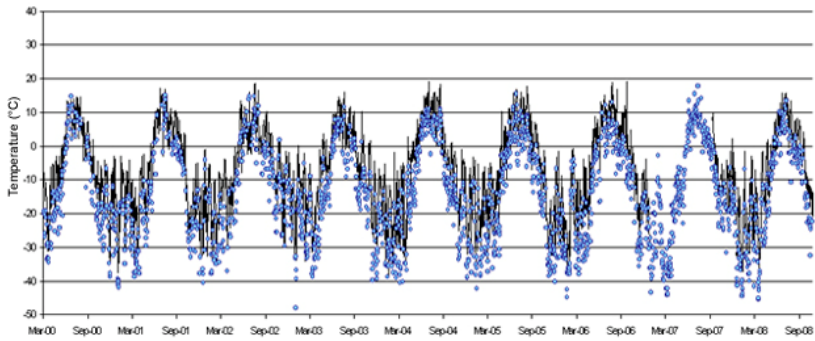

Mean Daily Aqua and Terra (Mean LST-Day / Night)

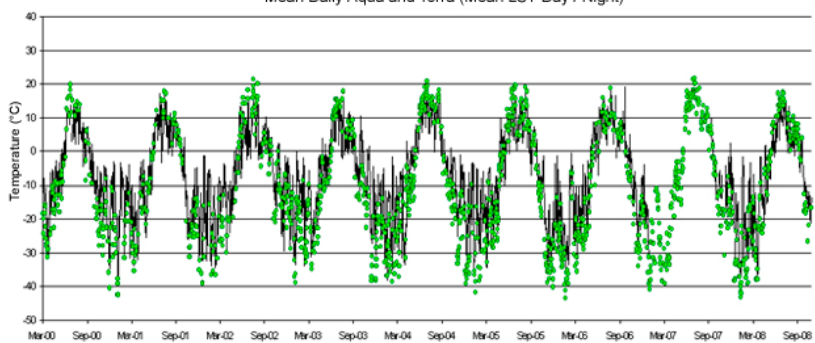

Fig. 3. Comparison between the mean LST (a) combined Terra/Aqua Day acquisitions (orange dots), (b) combined Terra/Aqua Night acquisitions (blue dots), and (c) combined Terra/Aqua Day/Night acquisitions (green dots), with mean daily Tair (black line) forIB1 pixel on Imnavait Basin site.

\subsection{Near-surface air temperature}

\subsubsection{Comparison of daytime and nighttime $T_{\text {air }}$ with LST for Aqua and Terra overpasses separately on an annual basis}

\section{Comparison of daytime temperatures}

The best relation between $T_{\text {air }}$ and LST is obtained in the middle of the day in both Alaska and Québec. As shown in Table 7, on an annual basis the correlation is high in both Québec and in Alaska for Aqua and Terra $(R>0.94)$. The MD is very small (around $-1{ }^{\circ} \mathrm{C}$ in Québec and around $+1{ }^{\circ} \mathrm{C}$ in Alaska) but the SD is large (around $6{ }^{\circ} \mathrm{C}$ in Québec and $5^{\circ} \mathrm{C}$ in Alaska), although it is much smaller than for the LST-GST comparison (Table 5). Table 7 shows the excellent agreement between LST-Day and $T_{\text {air }}$ in Aqua, Terra and the average of the two satellites. In Figs. $3 \mathrm{a}$ and $4 \mathrm{a}$, the daytime LST values (in orange) are superimposed on the daily mean $T_{\text {air }}$ curves (in black) of two different stations (IB1 pixel in
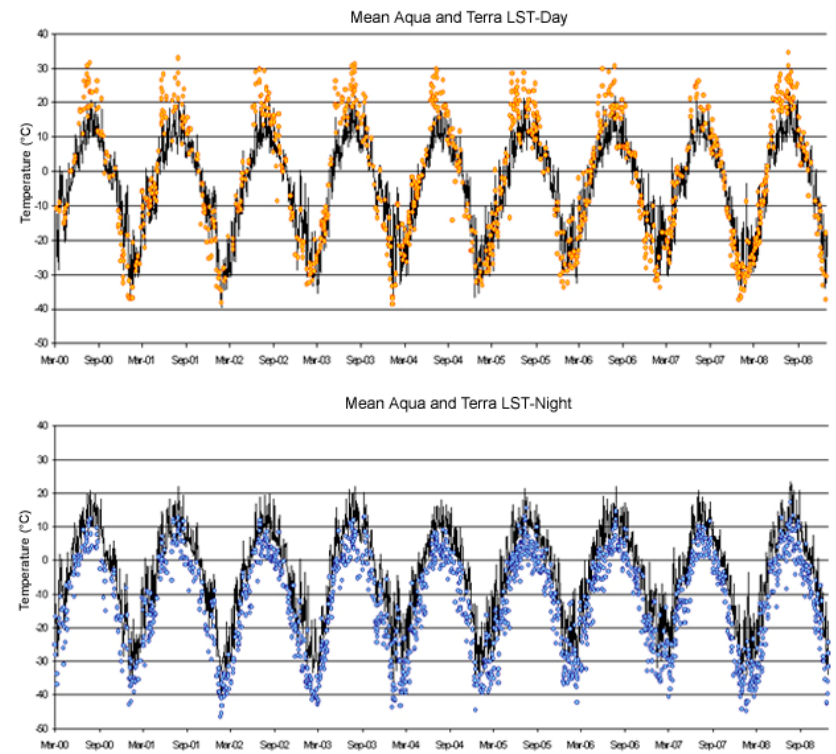

Mean Daily Aqua and Terra (Mean LST-Day / Night)

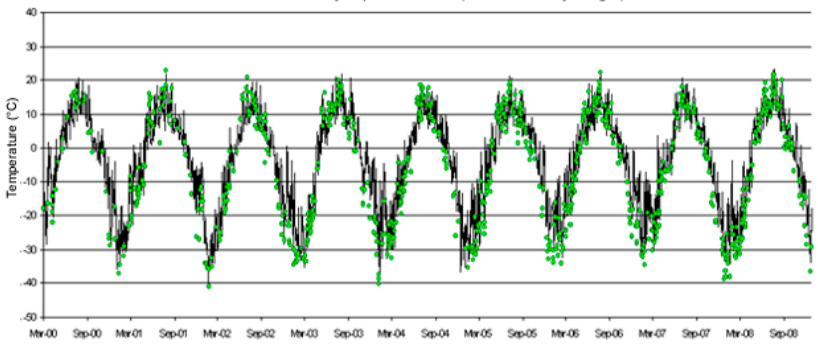

Fig. 4. Comparison between the mean LST (a) combined Terra/Aqua Day acquisitions (orange dots), (b) combined Terra/Aqua Nightacquisitions (blue dots), and (c) combined Terra/Aqua Day/Night acquisitions (green dots), with mean daily Tair (black line) forKuujjuaq2pixel at Kuujjuaq site.

Imnavait Basin and Kuujjuaq2 pixel at Kuujjuaq station). A similar agreement (not shown) is found at the other stations. These figures confirm the excellent correlation between LSTDay and $T_{\text {air }}$ as the LST (dots in figures) follows closely the $T_{\text {air }}$ annual oscillations. The LST-Day values are situated slightly above $T_{\text {air }}$, mostly during the summer period.

\section{Comparison of nighttime temperatures}

As shown in Table 7, on an annual basis, the correlations are high $(R>0.91)$ and better in Alaska than in Québec. The $\mathrm{MD}$ is quite high $\left(3\right.$ to $\left.5^{\circ} \mathrm{C}\right)$ in Alaska and even higher in Québec (about $6^{\circ} \mathrm{C}$ ), and the SD is similar to the daytime with $4{ }^{\circ} \mathrm{C}$ in Alaska and $6^{\circ} \mathrm{C}$ in Québec. In Figs. $3 \mathrm{~b}$ and $4 \mathrm{~b}$, the nighttime LSTs (in blue) are superimposed on the daily mean $T_{\text {air }}$ curves of IB1 and Kuujjuaq2. Figs $3 \mathrm{~b}$ and $4 \mathrm{~b}$ confirm the excellent correlation between LST-Night and $T_{\text {air }}$ as the LST follows closely the $T_{\text {air }}$ annual oscillations. Figs. $3 \mathrm{~b}$ and $4 \mathrm{~b}$ also show that the LST-Night observations 
are situated slightly below $T_{\text {air }}$, during the winter period and are clearly lower than $T_{\text {air }}$ during the summer months.

\section{Comparison of daily mean temperatures from Terra and Aqua separately and combined}

As shown earlier, LST-Day values tend to be higher than the mean daily $T_{\text {air }}$ while the LST-Night values tend to be lower. It is therefore worth examining how a mean value calculated from both LST-Day and LST-Night compares to the mean daily $T_{\text {air }}$ obtained from station measurements (Table 7). As shown in Table 7, on an annual basis, the correlations are very good $(R>0.96)$ which is still better than the $R$ values of daytime and nighttime taken separately for Aqua, Terra and Aqua/Terra in both Alaska and Québec. MD is reasonable $\left(1.3\right.$ to $\left.2.7^{\circ} \mathrm{C}\right)$ although SD stays relatively large (3.3 to 4.4), being smaller in Alaska than in Québec. The calculation of the mean greatly reduces the number of anomalous LST values. In Figs. $3 \mathrm{c}$ and $4 \mathrm{c}$, the mean LSTday/LST-night values (in green) are superimposed on the daily mean $T_{\text {air }}$ curves. In both the positive areas (summer temperatures) and the negative areas (winter temperatures) of the graphs, clusters of LST values are very close to $T_{\text {air. }}$. This demonstrates a general tendency of daily mean LST to be extremely well correlated (in synchrony) with daily mean $T_{\text {air }}\left(R=0.96, \mathrm{MD}=1.7^{\circ} \mathrm{C}\right.$ and $\mathrm{SD}=4.3^{\circ} \mathrm{C}$ in Québec; $R=0.98, \mathrm{MD}=1.9^{\circ} \mathrm{C}$ and $\mathrm{SD}=3.7^{\circ} \mathrm{C}$ in Alaska, see Table 7). In fact, too warm LST-day is evened out by too low LST-night, as shown in Figs. 3a, b and 4a, b.

\subsubsection{Comparison of daily mean $T_{\text {air }}$ with LST for Terra and Aqua combined during the snow free and snow cover periods}

Table 8 presents results of the comparison for each station between $T_{\text {air }}$ and LST over the complete year and for the snow free and snow cover periods separately. A stronger correlation exists during the snow cover compared to the snow free period. The MD is negative $\left(-2\right.$ to $-0.1^{\circ} \mathrm{C}$ ) for most stations (except West Dock, Ivotuk Shrub and Kujjuaq) during the snow free period; it is positive during the snow cover period $\left(1\right.$ to $\left.4{ }^{\circ} \mathrm{C}\right)$ for all the stations. SD values are relatively small (around $4^{\circ} \mathrm{C}$ ) and similar for the two periods. This illustrates that the LSTs are close to the $T_{\text {air }}$ values for both the snow free and snow cover periods. The correlations are indeed higher during the snow cover period (as shown for the West Dock station in Fig. 5) where only a few LST values show large differences with $T_{\text {air }}$. Finally, as the snow free period shows an absolute value of MD lower than the one for snow cover period $\left(1^{\circ} \mathrm{C}\right.$ versus $\left.3^{\circ} \mathrm{C}\right)$ and the SDs are similar for the two periods, one can conclude that the LSTs are closer to $T_{\text {air }}$ during the snow free period. The LSTs are nonetheless close to $T_{\text {air }}$ during the snow cover period.

\section{Discussion}

\subsection{Cloud detection}

The MODIS cloud detection algorithm does not perform perfectly over Arctic regions, as already reported in several papers (Langer et al., 2010, Westermann et al., 2011; Liu et al., 2010). By calculating the daily LST average using the four LST data sets available (Aqua/Terra, Day/Night), the number of anomalous LST values has been greatly reduced. It is worth noting prior to discussion that occasional anomalies are related to undetected clouds. Sometimes, one of the two sensors "observed" a cloud in LST-Day and therefore did not record a LST, while the other sensor retrieved a very cold LST, likely the upper- surface temperature of a cloud. It is not possible to be exactly sure of this, especially in winter when surface temperatures are also low, but at least the daily averaging would be compensated by the LST-Night measurements on that day. However, it is also possible that the two satellites did not identify the presence of clouds, in which case the mean daily LST would still be calculated and be anomalously low. Such anomalies are easily detected in summer when LST values are conspicuously too low for ground surface temperatures. In the implementation of an algorithm to map LST, one could set a threshold value to eliminate unreasonably low LST values during the snow free period (e.g. exclude values below $-15^{\circ} \mathrm{C}$ ).

\subsection{Comparison of LST with GST}

LSTs are clear-sky skin temperatures, i.e. the temperature at the air-soil (snow-free) or air-snow interface. The GSTs were taken at $3-5 \mathrm{~cm}$ depths in order to provide protection from the elements (weather and solar radiation) and wildlife. It is in these first few centimeters that ground temperatures are the most variable in time and space. Therefore, large differences between LSTs and GSTs can be expected. However, Québec stations show very good correlations (see Table 5) that can be explained by the structure of the soil surface. Around Sila and Tiki the ground surface is rocky and very little snow accumulates due to wind erosion; therefore the sensors always "see" a stable ground surface.

At other stations, the ground surface can be covered by vegetation (low or high), an organic layer or snow which act as buffer layers and have an impact on thermal exchanges with the atmosphere by decreasing or increasing the ground temperatures, depending on the season. The important insulating role of snow cover is well known. Snow cover extent and depth contribute by reducing ground cooling in winter (Goodrich, 1982). During the freezing period, the energy transfer occurs as release of latent heat. This process takes some time (i.e. the time necessary to convert all water into ice), and inversely in spring, during the melting period, when heat is absorbed to melt the ice in the ground surface layer. In the fall, this "zero curtain" effect is strongly dependent on 
Table 7. Mean Difference (MD), Standard Deviation (SD) and Correlation $(R)$ between $T_{\text {air }}$ and LST for daytime, nighttime and daily average from Aqua and Terra separately, and Aqua/Terra combined.

\begin{tabular}{|c|c|c|c|c|c|}
\hline & & & Daytime mean & Nighttime mean & Daily mean \\
\hline \multirow{9}{*}{ Alaska (Ak) } & \multirow[t]{3}{*}{ Terra } & MD & 0.7 & 2.9 & 1.4 \\
\hline & & $\mathrm{SD}$ & 5.1 & 4.4 & 4.1 \\
\hline & & $R$ & 0.97 & 0.96 & 0.97 \\
\hline & \multirow{3}{*}{ Aqua } & MD & 1.2 & 4.6 & 2.7 \\
\hline & & $\mathrm{SD}$ & 4.8 & 3.9 & 3.3 \\
\hline & & $R$ & 0.97 & 0.96 & 0.98 \\
\hline & \multirow{3}{*}{ Terra/Aqua } & MD & 0.9 & 3.5 & 1.9 \\
\hline & & $\mathrm{SD}$ & 5.0 & 4.4 & 3.7 \\
\hline & & $R$ & 0.96 & 0.95 & 0.98 \\
\hline \multirow{9}{*}{ Québec (Qc) } & \multirow[t]{3}{*}{ Terra } & MD & -0.4 & 5.6 & 1.6 \\
\hline & & $\mathrm{SD}$ & 5.7 & 5.4 & 4.3 \\
\hline & & $R$ & 0.96 & 0.91 & 0.96 \\
\hline & \multirow{3}{*}{ Aqua } & MD & -1.3 & 6.6 & 1.3 \\
\hline & & $\mathrm{SD}$ & 6.3 & 5.6 & 4.4 \\
\hline & & $R$ & 0.94 & 0.92 & 0.96 \\
\hline & \multirow{3}{*}{ Terra/Aqua } & MD & -0.5 & 6.1 & 1.7 \\
\hline & & $\mathrm{SD}$ & 5.9 & 5.6 & 4.3 \\
\hline & & $R$ & 0.95 & 0.91 & 0.96 \\
\hline \multirow{3}{*}{$\mathrm{Ak}$ and $\mathrm{Qc}$} & \multirow{3}{*}{ Terra/Aqua } & MD & 0.2 & 4.8 & 1.8 \\
\hline & & $\mathrm{SD}$ & 5.4 & 5.0 & 4.0 \\
\hline & & $R$ & 0.96 & 0.93 & 0.97 \\
\hline
\end{tabular}

the arrival of snow. If it is early, before the first frost, the snow insulates the ground from cold air temperatures. Then, to decrease the soil temperature, the air temperature must be sufficiently low for the ground to lose heat through the snow layer. On the other hand, if snow arrival is late, the soil has already started to freeze before the snow starts to play its insulation role. As seen in the regression plots of Fig. 2, the "zero curtain" associated with the effect of snow occurred when many daily consecutive field temperatures have values at $0{ }^{\circ} \mathrm{C}$, while MODIS continues to measure temperatures between -20 and $+10^{\circ} \mathrm{C}$. This effect lasts a relatively long period, as it persists for approximately one month at the Betty Pingo, Franklin Bluff and Western Kuparuk sites. The temperatures at Sila were also taken at a depth of $3 \mathrm{~cm}$, and the "zero curtain" effect is also visible (Fig. 2), but for a much shorter period of time (less than one week). This is due to the existence of a more rocky landscape with minimal water content in the soil surface layer and with the temperature probes being located in windy corridors where snow is blown; this factor results in less time required for water state changes at the beginning and ending of the thawing season. Furthermore, the correlation at Sila is especially high (0.96) because the satellites only acquired a few measurements during the time period when this effect occurred (mid-October to mid may). During spring, the insulation effect of snow is less efficient because of the thicker snow cover and the likely presence of ice lenses/crusts due to diurnal freeze and thaw cycles. The transition period in spring takes less time, about 10 days for the Greater Kuparuk River Basin stations and one week at Salluit.

\subsection{Comparison of LST with $T_{\text {air }}$}

The tendency for nighttime LST to be colder than $T_{\text {air }}$ throughout the year $\left(1.4<\mathrm{MD}<8.8^{\circ} \mathrm{C}\right.$, depending on station), with a mean MD night of $4.8^{\circ} \mathrm{C}$ (Table 7) occurs as result of heat transfer (e.g. radiative cooling of the ground and formation of an inversion layer) from the ground surface to the air above at night. Also, the role of annual changes in day length is important in the Arctic. "LST-Day" during winter corresponds to days without sunlight. Actually, overpass times at 09:00, 10:00, and 15:00 are "nighttime" acquisitions for many of these stations. This, plus the low sun angle during daylight, explains why there is less difference between day and night temperatures during the snow cover period. In the free snow period, even though the sun is above the horizon for much of the day, the zenith angle varies enough to make "day" temperatures warmer than "night" temperatures (which, for a part of the night hours, are sunlight hours). Therefore, the separation of the year into two parts (the snow 
Table 8. Mean Difference (MD), Standard Deviation (SD) and Correlation $(R)$ between $T_{\text {air }}$ and LST during complete year, snow free and snow cover periods for Aqua/Terra combined.

\begin{tabular}{lcccccccccccc}
\hline Tair-LST & \multicolumn{3}{c}{ Complete years } & \multicolumn{4}{c}{ Snow free period } & \multicolumn{3}{c}{ Snow cover period } \\
\hline Stations & $n$ & $R$ & MD & SD & $n$ & $R$ & MD & SD & nn & $R$ & MD & SD \\
\hline WD1 & 731 & 0.98 & 1.0 & 2.6 & 220 & 0.64 & 0.3 & 3.2 & 510 & 0.98 & 1.2 & 2.3 \\
WD2 & 831 & 0.98 & 1.0 & 2.6 & 245 & 0.68 & -0.1 & 3.0 & 584 & 0.98 & 1.4 & 2.2 \\
BPW1 & 1257 & 0.98 & 1.1 & 3.7 & 333 & 0.72 & -1.2 & 3.7 & 920 & 0.95 & 1.9 & 3.3 \\
FB1 & 1103 & 0.98 & 0.5 & 2.9 & 303 & 0.87 & -1.0 & 3.0 & 796 & 0.97 & 1.1 & 2.7 \\
FB2 & 1124 & 0.98 & 1.0 & 3.1 & 174 & 0.92 & -1.0 & 2.8 & 950 & 0.98 & 1.3 & 3.0 \\
SAG1 & 1360 & 0.97 & 2.3 & 4.4 & 354 & 0.89 & -1.7 & 3.3 & 1001 & 0.95 & 3.7 & 3.9 \\
WK1 & 1229 & 0.99 & 1.1 & 3.3 & 302 & 0.91 & -1.8 & 2.9 & 923 & 0.97 & 2.1 & 2.9 \\
WK2 & 1248 & 0.99 & 1.2 & 3.3 & 300 & 0.90 & -1.7 & 3.0 & 943 & 0.98 & 2.1 & 2.9 \\
UK1 & 1314 & 0.98 & 1.9 & 3.2 & 309 & 0.93 & -0.6 & 2.6 & 1002 & 0.97 & 2.7 & 3.0 \\
IB1 & 1297 & 0.97 & 5.1 & 4.8 & 307 & 0.93 & -0.2 & 2.7 & 988 & 0.94 & 6.8 & 4.1 \\
IB2 & 1318 & 0.97 & 4.7 & 4.5 & 319 & 0.93 & -0.1 & 2.9 & 996 & 0.95 & 6.2 & 3.9 \\
IvShb1 & 585 & 0.95 & 2.7 & 5.0 & 110 & 0.95 & 1.2 & 2.8 & 472 & 0.90 & 3.1 & 5.3 \\
IvMoss1 & 542 & 0.96 & 1.1 & 5.0 & 123 & 0.91 & -0.5 & 3.3 & 417 & 0.92 & 1.6 & 5.3 \\
\hline Alaska Stations & 1072 & 0.98 & 1.9 & 3.7 & 261 & 0.86 & -0.6 & 3.0 & 808 & 0.96 & 2.7 & 3.4 \\
SilaA1 & 376 & 0.98 & 1.4 & 3.2 & 113 & 0.80 & -0.9 & 3.2 & 262 & 0.97 & 2.5 & 2.7 \\
Sila1 & 93 & 0.98 & 2.6 & 3.0 & 24 & 0.80 & -0.1 & 4.0 & 69 & 0.98 & 3.6 & 1.9 \\
Tiki2 & 154 & 0.97 & 1.5 & 3.6 & 50 & 0.64 & -1.1 & 4.1 & 104 & 0.97 & 2.7 & 2.5 \\
Kangiq1 & 209 & 0.93 & 1.3 & 6.0 & 84 & 0.74 & -1.5 & 4.4 & 125 & 0.87 & 3.1 & 6.2 \\
Kangiq2 & 214 & 0.93 & 1.3 & 5.8 & 88 & 0.75 & -1.7 & 4.2 & 126 & 0.88 & 3.4 & 5.9 \\
Kujjuaq1 & 875 & 0.97 & 2.5 & 4.0 & 286 & 0.77 & 0.6 & 3.3 & 586 & 0.96 & 3.3 & 3.9 \\
Kujjuaq2 & 438 & 0.96 & 1.6 & 4.2 & 143 & 0.66 & 0.4 & 3.6 & 295 & 0.94 & 2.1 & 4.4 \\
\hline Québec Stations & 337 & 0.96 & 1.7 & 4.3 & 113 & 0.74 & -0.6 & 3.8 & 224 & 0.94 & 3.0 & 3.9 \\
\hline All Stations & 705 & 0.97 & 1.8 & 4.0 & 187 & 0.80 & -0.6 & 3.4 & 516 & 0.95 & 2.8 & 3.7 \\
\hline & & & & & & & & & & &
\end{tabular}

cover and free snow periods) does not take into account the difference in day lengths. The considered snow free period corresponds to the growing season at the high latitude. This period includes the summer solstice (up to $24 \mathrm{~h}$ of daylight) and ends after to the autumn equinox (September 21), which means that during this period the maximum day length is reached for meteorological stations above $60^{\circ} \mathrm{N}$. In turn, during this period, nights are very short. On the other hand, during the cold season, there are less daylight hours. For instance, Franklin Bluff station (about $69^{\circ} 53^{\prime} \mathrm{N}$ ) has $24 \mathrm{~h}$ of daylight between 17 May -26 July and no hours between 26 November and 15 January.

There appears to be differences between the LST taken in snowfree and snow cover periods (Table 8). The transitional periods of snow melt and soil freezing, which last between ten days to a month at these latitudes, were included in the snow cover season. In the middle of winter, the frozen snowcovered landscape is relatively homogeneous and, as a result, the complicating effects of soil and surface wetness are absent; the LST values represent those at the air-snow interface. However, it is different at the beginning and at the end of the defined snow cover period determined from the IMS satellite product (27 September-14 June in Alaska and 3 October-23
June in Québec), in particular for the period corresponding to the beginning of snowmelt and active layer thaw when extensive areas of stagnant water form due to the imperviousness of the underlying frozen soils. In permafrost areas, due to the shallow permafrost table, around $50 \mathrm{~cm}$ on the Alaskan sites (Kane et al., 2009), surface water is often stagnant. This water modifies the heat exchanges between the ground surface and the atmosphere, liberating warmer fluxes than frozen water. None of the heat exchanges appearing at the ground interface can be measured by the $2 \mathrm{~m}$ height air temperature instrumentation. As the snow cover period includes the period of snowmelt, the MD values in the snow free period are fluctuating around $0^{\circ} \mathrm{C}(-1.7<\mathrm{MD}<0.6$ for all stations with a mean of $-0.6^{\circ} \mathrm{C}$ ) (Table 8 ). Therefore, we can assume that during snowmelt the LST better represents the temperature of the melting snow on the ground than the $T_{\text {air }}$.

As indicated previously, the temperature of undetected clouds is lower than that of $T_{\text {air }}$, which provides at least a partial explanation for the differences during the snow cover period $\left(1.1<\mathrm{MD}<6.8{ }^{\circ} \mathrm{C}\right.$ with a mean of $\left.2.8{ }^{\circ} \mathrm{C}\right)$. Also, in the snow free period, $R$ values below or equal to 0.75 for 5 stations and 7 pixels (West Dock "WD1 and WD"), Betty Wet "BPW1", Tiki "Tiki2", Kangiqsuallujjuaq "Kangiq1 and 

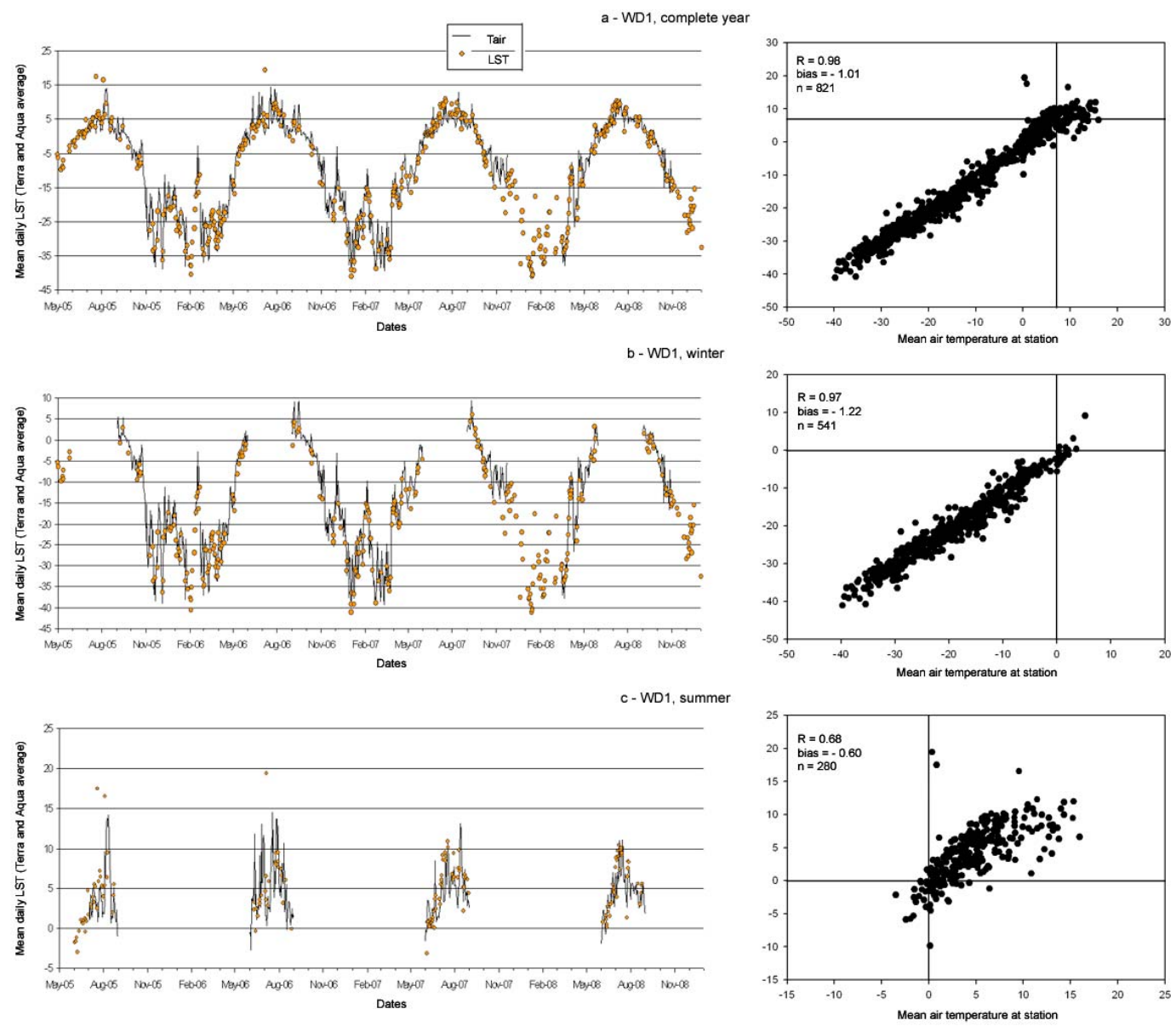

Fig. 5. Comparison between the mean daily LST (combined Day/Night/Terra/Aqua) and mean daily air temperature at West Dock (WD1) for (a) complete year, (b) winter, and (c) summer. On left, LST overlayed on meteorological station measurements, and on right relation between the two sets of measurements.

Kangiq2" and Kuujjuaq “Kuujjuaq2”), indicate a weaker relation between LST and $T_{\text {air }}$. As an example, in Fig. 5, the graphs for the WD1 site show the positive and negative temperature differences. For the other stations, $R$ values are all above 0.75 (up to 0.95 at Ivotuk Shrub). The presence of subgrid-scale water (see Table 2) within the MODIS pixels explains the more moderate relations between LSTs and $2 \mathrm{~m}$ height air temperature measurements at some of the sites. Globally, the temperature differences are larger in the snow cover period than in snow free period (Table 8). Snow free period differences are more frequently below $0{ }^{\circ} \mathrm{C}$ which means that LSTs are higher than $T_{\text {air }}$ during this period $\left(-1.7<\mathrm{MD}<0.6\right.$ for all stations with a mean of $\left.-0.6^{\circ} \mathrm{C}\right)$. During the snow cover period, differences show an opposite tendency. LSTs are lower than $T_{\text {air }}\left(1.1<\mathrm{MD}<6.8^{\circ} \mathrm{C}\right.$ with a mean of $2.8^{\circ} \mathrm{C}$ ). In absolute term, the differences in the snow free period are smaller than during snow cover period for all stations (Table 8).
At different time scales, it is possible to define different fluctuation periods. A period of one year corresponds to the annual solar radiation cycle while a period of one day corresponds to the diurnal solar radiation cycle. The difference between LST and $T_{\text {air }}$ can be large over a single day, but it diminishes over a monthly period. Seasonally, there is a slight tendency to yield a warmer LST temperature $\left(\mathrm{MD}=-0.6^{\circ} \mathrm{C}\right)$ during the snow free period and a colder temperature $\left(\mathrm{MD}=2.8^{\circ} \mathrm{C}\right)$ in the snow cover period. The mean annual difference for all stations combined is $1.8^{\circ} \mathrm{C}$, with a propensity for the LST to be below $T_{\text {air }}$.

It is clear from Table 8 that calculation of the mean annual LST removes the larger bias of the snow cover period from that of the snow free period. As a result, LSTs become closer to $T_{\text {air }}$ when averaged over the year but still, the differences observed show clearly that they are two different variables (clear-sky satellite "skin" surface-air interface temperature versus 1-3 $\mathrm{m}$ height air temperature). The differences are largely due to the nature and state of the surfaces being sensed within the MODIS pixels (e.g. vegetation, bare rock, 
surface water, wetness). Overall, regardless of surface type, LST and $T_{\text {air }}$ show a high degree of temporal coherence and on broad spatial and temporal (over a year) scales they follow the same trajectory. Since mean annual air temperatures are very important for calculating the thermal regime of permafrost, the annual means of LST, similar to $T_{\text {air }}$, are seen as useful for permafrost studies.

\section{Conclusions}

The major findings of this research can be summarized as follows:

1. LST, as expected, does not closely match GST especially when the ground is snow covered. However, LST values are very close to GSTs for stations located on rocky surfaces without water (in other words, in the absence of a buffer layer). The weaker correlations obtained between GST and LST are due to the effect of the different materials on the ground (the buffer layer), which in part contributes to the zero curtain effect during the transition between seasons.

2. LSTs were shown to be close to hourly $T_{\text {air }}$ measurements and even more so to daily $T_{\text {air }}$. The correlation between the two sets of measurements is stronger and MD is smaller when data are averaged on a seasonal basis. They are still better when averaged over a full year.

3. The mean daily LST yields stronger correlation with $T_{\text {air }}$ and GST when the data from the two satellites are combined than when values are taken separately (individual satellite, daytime, nighttime). It is therefore suggested to combine all the MODIS LSTs available to produce LST maps (e.g. mean monthly and annual) over permafrost regions as it has been tested by Hachem et al. (2008) over Northern Québec. The high correlation suggests that LSTs can be used as input in heat transfer models applied at regional to continental scales for mapping of permafrost. Each individual year showed a good correlation between annual averages of LST and $T_{\text {air. }}$ The temporal and spatial coverage as well as the $\sim 1 \mathrm{~km}^{2}$ footprint are great advantages for improving mapping precision and for monitoring annually the impacts of climate variations on permafrost.

4. In relation to the previous point, MODIS LSTs do not retrieve enough data over Arctic regions due to the abundance and frequency of clouds (Eastman et al., 2010) as to permit a continuous temporal coverage throughout a full annual cycle, and to calculate freezing and thawing indices. Filling the gaps in MODIS LST time series is necessary, either by temporal interpolation (Hachem et al., 2009) or by possibly combining them with temperature values obtained with coarser resolution passive microwave satellite data (e.g. Kohn and Royer, 2010; Royer and Poirier, 2010) or with data from reanalyses.

In summary, MODIS-derived LST is a viable data source for monitoring the surface thermal regime of regions underlain by permafrost and for modeling the seasonal evolution of the active layer. More investigations are needed to explore the effect of the buffer layer on LSTs to get the required GST.

Acknowledgements. This research was supported by grants from the Natural Sciences and Engineering Research Council of Canada (NSERC), ArcticNet, and Ouranos. All MODIS Land Surface Temperature data were obtained through the WIST website operated by NASA. Field data from the Alaskan sites were obtained via the website maintained by the Water and Environment Research Center

(http://www.uaf.edu/water/projects/NorthSlope/references.html), University of Alaska Fairbanks.

Field data from the Québec sites were obtained through the SILASAON network of meteorological stations and thermistor cables operated bythe Centre d'études nordiques, Université Laval (Québec), and data from Kuujjuaq were downloaded from Environment Canada's website

http://www.climat.meteo.gc.ca/climateData/canada_e.html? \\&.

Special thanks are extended to K. Tessier, Université Laval, for her help with the making of Fig. 1, and the anonymous reviewers for valuable comments and suggestions that helped improve the original manuscript.

Edited by: M. Stendel

\section{References}

Ackerman, S. A., Strabala K. I., Menzel, P. W. P., Frey, R. A., Moeller, C. C., and Gumley, L. E: Discriminating clear sky from clouds with MODIS, J. Geophys. Res., 103, 32141-32157, 1998.

Bosilovich, M. G.: A comparison of MODIS land surface temperature with in situ observations, Geophys. Res. Lett., 33, L20112, doi:10.1029/2006GL027519, 2006.

Bouchard, C.: Simulation du régime thermique des sols pergélisolés: essai du modèle "Tone", Master thesis, Université Laval, 137 pp., 1990.

Coll, C., Caselles, V., Galve, J. M., Valor, E., Niclos, R., Sanchez, J. M., and Rivas, R.:Ground measurements for the validation of land surface temperatures derived from AATSR and MODIS data, Remote Sens. Environ., 97, 288-300, doi:10.1016/j.rse.2005.05.007, 2005.

Coll, C., Wan, Z., and Galvem, J. M.: Temperature-based and radiance- based validations of the V5 MODIS land surface temperature product, J. Geophys. Res., 114, D20102, doi:10.1029/2009JD012038, 2009.

Christensen, T. R., Johansson, T., Akerman, J. H., Mastepanov, M., Malmer, N., Friborg, T., Crill, P., and Svensson, B. H.: Thawing sub-arctic permafrost: effects on vegetation and methane emissions, Geophys. Res. Lett., 31, L04501, doi:10.1029/2003GL018680, 2004.

Comiso, J. C.: Warming trends in the Arctic from clear sky satellite observations, J. Climate, 16, 3498-3510, 2003. 
Coops, N. C., Wulder, M. A., and Iwanicka, D.: Large area monitoring with a MODIS-based Disturbance Index (DI) sensitive to annual and seasonal variations, Remote Sens. Environ., 113, 1250-1261, doi:10.1016/j.rse.2010.01.005, 2009.

Crosman, E. T. and Horel, J. D.: MODIS-derived surface temperature of the Great Salt Lake, Remote Sens. Environ., 113, 73-81, doi:10.1016/j.rse.2008.08.013, 2009.

Eastman, R. and Warren, S. G.: Interannual Variations of Arctic Cloud Types in Relation to Sea Ice, J. Climate, 23, 4216-4232, doi:10.1175/2010JCLI3492.1, 2010.

Fernandes, R. A., Pavlic, G., Chen, W., and Fraser, R.: Canada-wide $1 \mathrm{~km}$ water fraction derived from National Topographic Data Base maps, Natural Resources Canada, Earth Science Sector, Ottawa, Ontario, Canada, availeble at: http://globalchange. nasa.gov/KeywordSearch/Metadata.do?Portal=GCMD $\backslash$ \&KeywordPath=Locations \$ $\backslash$ delimiter"026A30C\$VERTICAL+ LOCATION\$ $\backslash$ delimiter"026A30C\$SEA+SURFACE $\backslash$ \&OrigMetadataNode $=$ CANADA-CGDI $\backslash \&$ EntryId $=$ Canada_GeoGratis_1 kmWatFracNTDB $\backslash \&$ MetadataView $=$ Full $\backslash \&$ MetadataType $=0 \backslash \&$ lbnode $=$ mdlb3, last access: January 2012, 2002.

Gahé, E.: Géomorphologie cryogène et géophysique dans la région de Kangiqsualujjuaq, Ungava, Ph.D. thesis, Université Laval, 210 pp., 1987.

Galve, J. M., Coll, C., Caselles, V., Valor, E., Niclos, R., Sanchez, J. M., and Mira, M.: Simulation and validation of land surface temperature algorithms for MODIS and AATSR data, Tethys, 4, 27-32, doi:10.3369/tethys.2007.4.04, 2007.

Gleason, A. C. R., Prince, S. D., Goetz, S. J., and Small, J.: Effects of orbital drift on land surface temperature measured by AVHRR thermal sensors, Remote Sens. Environ., 79, 147-165, doi:S0034-4257(01)00269-3, 2002.

Goïta, K., Royer, A. B., and Bussières, N.: Characterization of land surface thermal structure from NOAA-AVHRR data over a Northern Ecosystem, Remote Sens. Environ., 60, 282-298, doi:S0034-4257(96)00211-8, 1997.

Goodrich, L.: The influence of snow cover on the ground thermal regime, Can. Geotech. J., 19, 421-432, 1982.

Hachem, S., Allard, M., and Duguay, C. R.: A new permafrost map of Québec-Labrador derived from near surface temperature data of the Moderate Resolution Imaging Spectroradiometer (MODIS), in: Proceedings of the 9th International Conference on Permafrost, 1, 591-596, 2008.

Hachem, S., Allard, M., and Duguay, C. R.: Using the MODIS land surface temperature product for mapping permafrost: an application to Northern Québec and Labrador, Canada, Permafrost Periglac., 20, 407-416, doi:10.1002/ppp.672, 2009.

Hall, D., Key, J., Casey, K., Riggs, G., and Cavalieri, D.: Sea ice surface temperature product from MODIS, IEEE Geosci. Remote S., 42, 1076-1087, doi:10.1109/TGRS.2004.825587, 2004.

Han, K.-S., Viau, A. A., and Anctil, F.: An Analysis of GOES and NOAA derived land surface temperatures estimated over a boreal forest, Int. J. Remote Sens., 25, 4761-4780, doi:10.1080/01431160410001680446, 2004.

Heim, B., Bartsch, A., Elger, K., Lantuit, H., Boike, J., Muster, S., Langer, M., Duguay, C., Hachem, S., Soliman, A., Paulik, C., Strozzi, T., and Seifert, F. M.: ESA DUE Permafrost: An earth observation (EO) permafrost monitoring system, EARSeL eProceedings, 10, 73-82, 2011.
Hinzman, L. D., Goering, D. J., and Kane, D. L.: A distributed thermal model for calculating soil temperature profiles and depth of thaw in permafrost regions, J. Geophys. Res., 103, 2897528991, 1998.

Hinzman, L. D., Bettez, N. D., Bolton, W. R., Chapin III, F. S., Dyurgerov, M. B., Fastie, C. L., Griffith, B., Hollister, R. D., Hope, A., Huntington, H. P., Jensen, A. M., Jia, G. J., Jorgenson, T., Kane, D. L., Klein, D. R., Kofinas, G., Lynch, A. H., Lloyd, A. H., McGuire, A. D., Nelson, F. E., Oechel, W. C., Osterkamp, T. E., Racine, C. H., Romanowsky, V. E., Stone, R. S., Stow, D. A., Sturm, M., Tweedie, C. E., Vourlitis, G. L., Walker, M. D., Walker, D. A., Webber, P. J., Welker, J. M., Winker, K., and Yoshikawa, K.: Evidence and implications of recent climate change in Northern Alaska and other arctic regions, Climatic Change, 72, 251-298, doi:10.1007/s10584-005-5352-2, 2005.

Hook, S. J., Vaughan, R. G., Tonooka, H., and Schladow, S. G.: Absolute radiometric inflight validation of mid infrared and thermal infrared data from ASTER and MODIS on the Terra Spacecraft using the Lake Tahoe, CA/NV, USA, automated validation site, IEEE Geosci. Remote S., 45, 1798-1807, doi:10.1109/TGRS.2007.894564, 2007.

IPCC Report 2007: Contribution of Working Groups I, II and III to the Fourth Assessment Report of the Intergovernmental Panel on Climate Change, Core Writing Team, edited by: Pachauri, R. K. and Reisinger, A., IPCC, Geneva, Switzerland, pp.104, 2007.

Jia, G. J. and Epstein, H. E.: Controls over intra-seasonal dynamics of AVHRR NDVI for the Arctic tundra in Northern Alaska, Int. J. Remote Sens., 25, 1547-1564, doi:10.1080/0143116021000023925, 2004.

Jin, M. and Treadon, R. E.: Correcting the orbit drift effect on AVHRR land surface skin temperature measurements, Int. J. Remote Sens., 24, 4543-4558, doi:10.1080/0143116031000095943, 2003.

Kane, D. L.: High-latitude hydrology, what do we know?, Hydrol. Process., 19, 2453-2454, doi:10.1002/hyp.5929, 2005

Kane, D. L. and Hinzman, L. D.: Climate data from the North Slope Hydrology Research project, University of Alaska Fairbanks, Water and Environmental Research Center, available at: http://ine.uaf.edu/werc/projects/NorthSlope/ Fairbanks, Alaska, variously paged, Retrieval August 2009.

Klene, A. E., Nelson, F. E., and Shiklomanov, N. I.: The N-factor in Natural Landscapes: Variability of Air and Soil-Surface Temperatures, Kuparuk River Basin, Alaska,USA, Arctic and Alpine Research, 33, 140-148, 2001.

Kohn, J. and Royer, A.: AMSR-E data inversion for soil temperature estimation under snow cover, Remote Sens. Environ., 114, 2951-2961, doi:10.1016/j.rse.2010.08.002, 2010.

Langer, M., Westermann, S., and Boike, J.: Spatial and temporal variations of summer surface temperatures of wet polygonal tundra in Siberia - implications for MODIS LST based permafrost monitoring, Remote Sens. Environ., 114, 2059-2069, doi:10.1016/j.rse.2010.04.012, 2010.

Liu, Y., Ackerman, S., Maddux, B., Key, J., Frey, R.: Errors in cloud detection over the Arctic using a satellite imager and implications for observing feedback mechanisms, J. Climate, 23, 1894-1907, doi:10.1175/2009JCLI3386.1, 2010.

Mialon, A., Royer, A., Fily, M., and Picard, G.: Daily microwavederived surface temperature over Canada/Alaska, J. Appl. Meteorol. Clim., 46, 591-604, doi:10.1175/JAM2485.1, 2007. 
Marchenko, S., Hachem, S., Romanovsky, V., and Duguay, C.: Permafrost and active layer modeling in the Northern Eurasia using MODIS Land Surface Temperature as an input data, Geophys. Res. Abstracts, 11, 2009-11077, 2009.

Romanovsky, V. E., Burgess, M., Smith, S., Yoshikawa, K., and Brown, J.: Permafrost temperature records: indicators of climate change, EOS Transactions, 83, 593-594, 2002.

Royer, A. and Poirier, S.: Surface temperature spatial and temporal variations in North America from homogenized satellite SMMR - SSM/I microwave measurements and reanalysis for 1979-2008, J. Geophys. Res.-Atmos., 115, D08110, doi:10.1029/2009JD012760, 2010.

Sazonova, T. and Romanovsky, V. E.: A model for regional scale estimation of temporal and spatial variability of active layer thickness and mean annual ground temperatures, Permafrost Periglac., 14, 125-139, doi:10.1002/ppp.449, 2003.

Schubert, P., Eklundh, L., Lund, M., and Nilsson, M.: Estimations northern peatland $\mathrm{CO}_{2}$ exchange from MODIS time series data, Remote Sens. Environ., 114, 1178-1189, doi:10.1175/JAM2485.1, 2010.

Serreze, M. C., Walsh, J. E., Chapin III, F. S., Osterkamp, T. E., Dyurgerov, M. B., Romanovsky, V. E., Oechel, W. C., Morison, J., Zhang, T., and Barry, R. G.: The observational evidence of recent change in the northern high latitude environment, Climatic Change, 46, 159-207, doi:10.1023/A:1005504031923, 2000.

Shiklomanov, N. I. and Nelson, F. E.: Active-layer mapping at regional scales: a $13 \mathrm{yr}$ spatial time series for the Kuparuk Region, North-Central Alaska, Permafrost Periglac., 13, 219-230, doi:10.1002/ppp.425, 2002.

Shiklomanov, N. I., Anisimov, O. A., Zhang, T., Marchenko, S., Nelson, F. E., and Oelke, C.: Comparison of model-produced active layer fields: results for northern Alaska, J. Geophys. Res., 112, F02S10, doi:10.1029/2006JF000571, 2007.

Snyder, W. C., Wan, Z., Zhang, Y., and Feng, Y.-Z.: Requirements for satellite land surface temperature validation using a Silt Playa, Remote Sens. Environ., 6, 279-289, 1997.

Traoré, P. C. S., Royer, A. B., and Goïta, K.: Land surface temperature time series derived from weekly AVHRR GVI composite datasets: Potential and constraints for Northern Latitudes, Can. J. Remote Sens., 4, 390-400, 1997.

Wan, Z.: MODIS Land Surface Temperature products user's guide, Institute for Computational Earth System Science, University of California, Santa Barbara, CA, availeble at: http://www.icess.ucsb.edu/modis/LstUsrGuide/ MODIS_LST_products_Users_guide_C5.pdf, last access: 27 April 2011, 2007.
Wan, Z.: New refinements and validation of the MODIS landsurface temperature/emissivity products, Remote Sens. Environ., 112, 59-74, doi:10.1016/j.rse.2006.06.026, 2008.

Wan, Z. and Dozier, J.: A generalized split-window algorithm for retrieving land-surface temperature from space, IEEE Geosci. Remote S., 34, 892-905, doi:10.1109/36.508406, 1996.

Wan, Z. and Li, Z.-L.: A physics-based algorithm for retrieving land-surface emissivity and temperature from EOS/MODIS data, IEEE Geosci. Remote S., 35, 980-996, doi:10.1109/36602541, 1997.

Wan, Z. and Li, Z-L.: Radiance-based validation of the V5 MODIS land-surface temperature product, Int. J. Remote Sens., 29, 5373-5395, doi:10.1080/01431160802036565, 2008.

Wan, Z., Zhang, Y., Li, Z.-L., Wang, R., Salomonson, V.V., Yves, A., Bosseno, R., and Hanocq, J. F.: Preliminary estimate of calibration of the Moderate Resolution Imaging Spectroradiometer thermal infrared data using Lake Titicaca, Remote Sens. Environ., 80, 497-515, doi:10.1016/S0034-4257(01)00327-3, 2002a.

Wan, Z., Zhang, Y., Zhang, Q., and Li Z.-L.: Validation of the landsurface temperature products retrieved from Terra Moderate Resolution Imaging Spectroradiometer data, Remote Sens. Environ., 83, 163-180, doi:10.1016/S0034-4257(02)00093-7, 2002b.

Wan, Z., Zhang, Y., Zhang, Q., and Li Z.-L.: Quality assessment and validation of the MODIS global land surface temperature, Int. J. Remote Sens., 25, 261-274, doi:10.1080/0143116031000116417, 2004.

Westermann, S., Langer, M., and Boike, J.: Spatial and temporal variations of summer surface temperatures of high-arctic tundra on Svalbard - Implications for MODIS LST based permafrost monitoring, Remote Sens. Environ., 115, 908-922, doi:10.1016/j.rse.2010.11.018, 2011.

Wolfe, R. E., Nishihama, M., Fleig, A. J., Kuyper, J. A., Roy, D. P., Storey, J. C., Patt, F. S.: Achieving sub-pixel geolocation accuracy in support of MODIS land science, Remote Sens. Environ., 83, 31-49, doi:10.1016/S0034-4257(02)00085-8, 2002.

Zhou, L., Tucker, C. J., Kaufmann, R. K., Slayback, D. A., Shabanov, N. V., and Myneni, R. B.: Variations in northern vegetation activity inferred from satellite data of vegetation index during 1981 to 1999, J. Geophys. Res.-Atmos., 106, 20069-20083, 2001. 